Portland State University

PDXScholar

\title{
Trade Invoicing in Major Currencies in the 1970s-1990s: Lessons for Renminbi Internationalization
}

Hiro Ito

Portland State University, ito@pdx.edu

Kawai Masahiro

Tokyo University

Follow this and additional works at: https://pdxscholar.library.pdx.edu/econ_fac

Part of the International Economics Commons

Let us know how access to this document benefits you.

\section{Citation Details}

Ito, Hiro, and Masahiro Kawai. "Trade invoicing in major currencies in the 1970s-1990s: Lessons for renminbi internationalization." Journal of the Japanese and International Economies 42 (2016): 123-145.

This Post-Print is brought to you for free and open access. It has been accepted for inclusion in Economics Faculty Publications and Presentations by an authorized administrator of PDXScholar. Please contact us if we can make this document more accessible: pdxscholar@pdx.edu. 
First Draft: January 2016

Revised: September 2016

\title{
Trade Invoicing in Major Currencies in the 1970s-1990s:
}

Lessons for Renminbi Internationalization

\author{
ITO Hiro * \\ Portland State University \\ KAWAI Masahiro ** \\ University of Tokyo
}

\begin{abstract}
In this paper, we investigate how much a major currency is used for trade invoicing by focusing primarily on the experiences of the U.S. dollar, the Japanese yen, and the Deutsche mark (DM) in the 1970s through the 1990s. We then attempt to draw lessons for China's renminbi (RMB) internationalization. Our data on the shares of the three major currencies in export invoicing show that the dollar was unequivocally a global invoicing currency, and that the DM was the most important regional currency in Europe while the yen was never a global or a regional currency. DM invoicing was driven by European countries' trade ties with Germany. In contrast, the yen was not widely used for trade invoicing by Asia-Oceania countries despite the latter's strong trade ties with Japan. Our regression analysis on the determinants of the major currency share in trade invoicing (also including UK pound sterling, the French franc, the Italian lira, and the Swiss franc) in the 1970-1998 period shows that the invoicing share of a major currency tended to be positively affected by the degree of other economies' trade ties with the major currency country and negatively affected by the degree of their financial development or openness. Also, the major currency share in trade invoicing was affected by both other economies' assigned weights of the major currency in their implicit currency baskets and these economies' trade shares with major-currency zone countries. Economies belonging to the U.S. dollar (or DM) zone tended to invoice their trade more in the dollar (or DM) and less in the DM (or dollar). The use of yen for trade invoicing was not much affected by these factors. European countries largely belonged to the DM zone and tended to use the DM for trade invoicing, whereas Asia-Oceania countries belonged mainly to the U.S. dollar zone, leading to a high degree of dollar use. We also find that major currency countries tended to invoice their trade in their own currencies when they had a large presence in international trade, high levels of per capita income, and financial markets that were developed and open. For China, its low level of per capita income, limited financial openness, and the presence of U.S. dollar zone countries in Asia stand as a challenge to the nation's ambition to promote the RMB as a major trade-invoicing currency.
\end{abstract}

Keywords: Trade invoicing, Invoicing currency, International currency, RMB internationalization

\section{JEL codes: F32,F41}

Acknowledgement: This research was conducted while Ito was a visiting fellow at RIETI. Ito is grateful for their generous support and hospitality. The authors thank anonymous referees, Etsuro Shioji and other participants at the TRIO conference for constructive comments on the earlier draft. Ito thanks Portland State University for financial support. Kawai thanks the Japan Society for the Promotion of Science (JSPS) for financial support through JSPS KAKENHI Grant Number 16K03733.

\footnotetext{
* Hiro Ito: Department of Economics, Portland State University, 1721 SW Broadway, Portland, OR 97201, U.S.A. Tel/Fax: +1-503725-3930/3945. Email: ito@pdx.edu

** Masahiro Kawai: Graduate School of Public Policy, University of Tokyo, 7-3-1 Hongo, Bunkyo-ku, Tokyo, 113-0033 Japan. Tel: +81-3-5841-1530. Email: mkawai@p.u-tokyo.ac.jp.
} 


\section{Introduction}

In recent years, the issue of renminbi (RMB) internationalization has been actively debated. The global financial crisis of 2007-09 raised questions about the desirability of the current US dollar-dominant international monetary system. Even though China and other emerging economies have grown fast with their presence rising in the world economy over the last two decades, their interests do not seem to be adequately reflected in the current international monetary system. Thus, with China's rapid rise as a global economic power, its authorities decided to promote the RMB as an international currency and increase its use for international trade, investment and finance. ${ }^{1}$

As a result, the international status of the RMB has been on the rise. According to the Society for Worldwide Interbank Financial Telecommunication (SWIFT), the RMB became the world's fourth most used payments currency in August 2015, overtaking the Japanese yen. ${ }^{2}$ Data from the People's Bank of China indicate that, as of early 2016, RMB cross-border trade settlement accounted for $26 \%$ of China's total trade.

Reflecting the rise of the currency, the International Monetary Fund (IMF) has included the RMB, since October 2016, in the basket for the special drawing rights (SDR), along with the four incumbent reserve currencies: the U.S. dollar, euro, Japanese yen, and U.K. pound. Although the use of the RMB as official assets is still limited, this is an important first step for the currency to become a major reserve currency.

While the RMB is growing as an international currency, a natural question that arises is, what kind of international currency will it become? Will it become like the U.S. dollar which functions as the dominant global currency and as last-resort international liquidity? Or, will it function as a regional currency as the euro does in Europe ${ }^{3}$ Or, will it become an international currency like the Japanese yen, which has failed to become neither a global nor a regional currency?

While we cannot predict the future of the RMB, we can learn some lessons from history. In this paper, we focus on one aspect of international currency among the several as identified by

\footnotetext{
1 See Eichengreen and Kawai (2015) for recent trends, issues and challenges in RMB internationalization.

${ }^{2} \mathrm{RMB}$ accounted for $2.8 \%$ of global payments in terms of value, still small compared to the top three in the ranking; the U.S. dollar at $44.8 \%$, euro at $27.2 \%$, and pound at $8.5 \%$ (yen at $2.78 \%$ ). However, it is a rapid rise considering that it ranked 12th with a share of $0.84 \%$ in 2012.

3 Eichengreen and Lombardi (2015) investigate these questions.
} 
Kenen (1983), that is, how much a national currency is used for invoicing international trade. Currency invoicing in trade is one of the earlier steps for any national currency to become a major international currency. This exercise can provide some insight into the future potential for, or impediments to, the RMB becoming a major trade invoicing currency.

Why does currency invoicing in trade matter? Theoretically, in the world with complete financial markets and perfectly substitutable financial assets, the choice of currency for trade invoicing would not be an issue. However, in reality, financial markets are not complete and financial assets denominated in different currencies are not perfectly substitutable-due to differences in the degree of currency convertibility, political risk, financial market depth and liquidity, and various types of transaction costs.

In the absence of complete markets and perfectly substitutable financial assets, the selection of currency for trade invoicing affects the allocation of exchange risk between exporters and importers. ${ }^{4}$ The choice of currency invoicing is also related to the choice of product pricing, that is, whether a producer prices her product in her own currency (called producer pricing) or in the currency of the export market (local currency pricing). ${ }^{5}$ Although expost negotiations on the allocation of exchange risk through price changes are possible after observing exchange rate changes, such negotiations are usually costly. Indeed, Gopinath (2015) finds that import prices denominated in the currency of invoicing tend not to be so sensitive to exchange rate changes at horizons of up to two years. This suggests that the choice of currency invoicing reflects the degree of pricing power that an exporter might have in the export market, and the structure and characteristics of trading economies.

While there is relatively rich theoretical literature on the choice of currency in trade invoicing, the empirical literature has been thin, largely due to limited data availability. As only a small number of countries have collected and published currency invoicing data, it has been

\footnotetext{
4 In fact, the move to the generalized floating system in 1973, following the breakdown of the Bretton Woods system, was accompanied by higher levels of exchange-rate fluctuations and uncertainty, which made the issue of currency choice for trade invoicing more important than before.

5 The choice of product pricing involves a question of whether to avoid price or demand uncertainty. When a producer prices her product in her home currency, she can avoid price uncertainty but faces uncertain demand as it is subject to exchange rate fluctuations. When a producer prices her product in the local currency of the export market, she can minimize demand uncertainty but faces price uncertainty due to exchange rate changes.
} 
difficult for researchers to use a comprehensive dataset on the shares of currencies in trade invoicing. 6

The US dollar is 'the' global currency today, functioning as the most dominant currency for trade invoicing, for cross-border asset and liability holding, in foreign exchange markets, and as official reserve assets. The DM was the most important regional currency in Europe whose role was succeeded by the euro. The yen was and still is never a global nor a regional currency, as its use for trade invoicing remains limited even in Japan's trade. In our econometric analysis, we restrict our sample period to the 1970s through the 1990s. By examining the determinants of the shares of major currencies in trade invoicing and the different patterns across these currencies, we hope to draw some lessons for the RMB.

In this paper, we expand and update the database on the shares of major currencies used for trade invoicing first compiled by Ito and Chinn (2015). The updated dataset contains data on the shares of not only the U.S. dollar, the Japanese yen, and the Deutsche mark but also other major currencies such as the euro, U.K. pound sterling, French franc, Italian lira, and Swiss franc, used for both export and import invoicing. The dataset includes the shares of these major currencies in trade invoicing used by both the major currency countries and by non-major currency economies.

The paper is organized as follows. In Section 2, we explain briefly the dataset and review stylized facts on the use of major currencies, especially the U.S. dollar, the Japanese yen, and the Deutsche mark. In Section 3, we conduct an empirical analysis to investigate the determinants of the major currency share in trade invoicing, by using data for the above three currencies as well as U.K. pound, French franc, Italian lira, and Swiss franc. We first run regressions from the perspective of non-major currency economies. We augment our analysis in two ways; first, by examining whether 'currency zone' variables matter for the choice of a major currency for trade invoicing; and second, by studying different patterns of trade invoicing among the major currencies. Then, we run regressions from the perspective of major currency countries to investigate the determinants of major-currency invoicing. In Section 4, we use our empirical

\footnotetext{
${ }^{6}$ Hence, most empirical studies on currency invoicing have focused on individual countries, as in Donnenfeld and Haug (2003) for Canada, Wilander (2004) for Sweden, Ligthart and Werner (2012) for Norway, Ito, et al. (2010, 2012) for Japan, and Da Silva (2004) for the Netherlands. Goldberg and Tille (2008) and Kamps (2006) are the exceptions, conducting cross-country analysis on the determinants of trade invoicing, though the scope of country coverage tends to be small and highly unbalanced. For more literature review, refer to ECB (2005), Kamps (2006), Goldberg and Tille (2008), Maziad, et al. (2011), Aubion (2012), and Ito and Chinn (2015).
} 
analysis to draw some lessons and implications for further internationalization of the RMB. In Section 5, we provide concluding remarks.

\section{Trade Invoicing Currency Dataset and Stylized Facts}

\subsection{Data on Currency Shares in Trade Invoicing}

In this study, we use the updated and expanded version of the dataset initially constructed by Ito and Chinn (2015). The initial version contained the datasets developed by Goldberg and Tille (2008) and Kamps (2006), while also including data collected from the websites of central banks and other government agencies, as well as from other studies that examined the issue of currency invoicing for trade. This dataset included only the shares of the U.S. dollar, the euro, and home currencies used for trade invoicing and settlement. The new augmented dataset is much more extensive than the initial one. First, a significant amount of new data is added, such as data from past studies and data obtained through personal communications. Second, coverage of major currencies is expanded to include trade invoicing in the Japanese yen, U.K. pound, Deutsche mark (DM), Dutch guilder, French franc, Italian lira, Swiss franc, and others. ${ }^{7}$ Third, the sample period is enlarged, going back to the 1970s for some European major currencies. Fourth, sample country data are broadened to include developing and emerging economies such as Brazil, Chile, and India. ${ }^{8}$

The new dataset includes 56 economies. However, the coverage of economies and years is subject to data availability; it varies depending on the invoicing currency and whether currency invoicing data are for exports or imports. While Japan provides the most comprehensive data, going back to 1969 for both exports and imports, other economies report less comprehensive data, sometimes for only a single year or a single currency (often the US dollar or the euro) in

\footnotetext{
7 The new dataset also includes the shares of the Canadian dollar, Belgium franc, Danish krone, Norwegian krone, Swedish krone, the RMB, Singaporean dollar, Hong Kong dollar, Australian dollar, and New Zealand dollar. However, data availability for these currencies is highly limited.

${ }^{8}$ It must be noted that the dataset mixes data on currencies used for invoicing or settlements for trade transactions. Strictly speaking, the currency for trade invoicing and that for actual settlement may differ. However, reporting government agencies often do not make it clear whether they report invoicing or settlement data. Page (1977, 1981) argues that differences between invoicing and settlement is sometimes negligible. However, for a newly internationalized currency such as the RMB, the difference can be significant. For more details on the deviation between RMB invoicing and settlement, refer to Yu (2012).
} 
some cases. For most EU countries, data are available from 1999 through 2014 but often for the euro share only. ${ }^{9}$

\subsection{Stylized Facts}

Using the new dataset of currency shares in trade invoicing, we first review how the choice of trade invoicing currency has evolved over time and differs among countries or currencies. We focus on the yen, the DM, and the U.S. dollar.

Japan and Germany. Panel (a) of Figure 1 illustrates the shares of major currencies used for export and import invoicing in Japan for the period 1969 to 2014. It shows that, as of the end of the 1960s - a few years after the yen achieved current account convertibility in 1964-only $0.6 \%$ of Japan's export was invoiced in yen, while essentially none of Japan's import was invoiced in the currency. The share of yen invoicing for export started to rise in the 1970s and peaked in 1983, hitting 42\%, while the share of U.S. dollar invoicing evolved as a mirror image of the yen share, falling from above $90 \%$ to about $50 \%$. Despite the rapid rise in yen invoicing for export in the 1970s, the share of yen invoicing for import reached only $3 \%$ by the end of the decade. From the mid-1980s, however, the share of yen in export invoicing stopped rising and hovered at around 35-40\%, and the share of the U.S. dollar hovered at around 50\%. In contrast, the share of yen in import invoicing continued to rise and stabilized at around $20-25 \%$, while the dollar share remained higher at around 70\%. Overall, although Japan relaxed regulatory controls on the use of the yen for cross-border transactions in the first half of the 1980s, one does not observe an upward shift in the use of the yen for export or import invoicing. Despite the policy efforts of encouraging yen internationalization in the 1990s, the currency has failed to become the dominant invoicing currency even for Japan's own trade.

This is in sharp contrast with Germany and the DM as illustrated in Panel (b). The DM share in export invoicing was already above $80 \%$ in the early 1970 s, marking a peak of $89 \%$ in 1975, and remained consistently high at around $80 \%$ for most of the 1980s, though the share gradually declined in the 1990s. The DM share in import invoicing rose from $50 \%$ in 1972 , peaking at $56 \%$ in 1992 . While the U.S. dollar played an important role as an invoicing currency in Japan, the dollar played a minor role in Germany though it was used slightly more for import

\footnotetext{
9 Recently, the EU started a more complete survey on currency invoicing, but it covers only 2010, 2012 , and 2014. Indonesia, Korea, and Thailand publish long and detailed trade invoicing data in terms of the coverage of currencies.
} 
than for export invoicing. Also, when the shares of DM and euro invoicing in the last half of the 1990s are compared, one can see that DM invoicing was relatively smoothly replaced with euro invoicing once the single currency was introduced in 1999 - the share remained above $60 \%$.

Frankel (2011) argues that both Japan and West Germany were reluctant to internationalize their currencies when these currencies began to rise as international currencies in the 1980s. The reason for this reluctance was that their authorities feared that currency internationalization would lead to exchange rate appreciation - thereby hurting the international price competitiveness of tradable products - and that it would make autonomous monetary policymaking difficult. In the 1990s, Japan changed its policy stance and began to promote yen internationalization. However, the economy soon fell into a long-term stagnation with banking sector difficulties, thereby limiting the progress of yen internationalization. In contrast, DM internationalization was not hampered in the 1990s and was smoothly succeeded by the euro in 1999.

Partners of major currency countries. Figure 2 provides useful insight into the different degrees of the use of major currencies for trade invoicing from the perspective of partner economies. Figure 2 (a) focuses on Japan. It plots the average share of yen export invoicing used by each of Japan's trading partners against the average share of such partner's exports to Japan in total exports for the 1995-1999 period. One would expect the yen invoicing share to be proportional to the share of Japan as a destination of partners' exports. However, all the observations are plotted below the 45 degree line, indicating that Japan's partners did not invoice their exports in yen as much as their export shares with Japan might have suggested. Only Israel, Korea, Thailand, and the U.S. appeared to invoice their exports in yen more than did other partners, but still their shares were low, at most $7 \%$.

Figure 2 (b) illustrates the case of the U.S. It plots the U.S. dollar share for export invoicing used by each U.S. partner against the share of the partner's exports to the U.S. in its total exports. The U.S. dollar invoicing pattern is in sharp contrast to the yen invoicing pattern. All observations except New Zealand are plotted above the 45 degree line, indicating that U.S. partner economies tended to invoice their exports in the U.S. dollar much more than proportionally to the share of their exports to the U.S. ${ }^{10}$ Thus the U.S. dollar played a dominant role as a trade invoicing currency.

${ }^{10}$ We must note that the scale in Figure 2 (b) is different from Figure 2 (a). 
The DM was an intermediate case between the U.S. dollar and the yen as shown in Figure 2 (c). Germany's partners tended to be distributed rather close to the 45 degree line. Romania was an exception in that it invoiced its export in the DM more than proportionally to the share of its exports to Germany. Major European economies such as Italy, the Netherlands, and France tended to invoice their exports in the DM, reflecting their trade ties with Germany. In this sense, DM invoicing was driven by trade and therefore became a regional currency.

The euro invoicing pattern is in between DM and dollar invoicing using the average data for the 2009-2013 period, as reported in Figure 2 (d). Its share for export invoicing fully reflects partners' export share with euro-area economies as in the case of the DM share. For Eastern European countries, the euro share is even higher than the export share as in the case of the U.S. dollar. Many European countries that used to use their home currencies or the DM for export invoicing switched to euro invoicing once they joined the Euro Area, which explains relatively high euro invoicing shares even though the currency was new. ${ }^{11}$

Next, we take a look at how the export invoicing shares of the yen and the DM have changed over time from the perspective of partner economies. Figures 3-1 and 3-2 illustrate changes over time in the yen and DM shares for export invoicing against the export shares with Japan and Germany, respectively, for selected economies. For comparison purposes, Figure 3-3 depicts the case of the euro. In each diagram, if the invoicing currency plays an increasingly important role, the observation points (the combinations of the currency share and the export share with the currency issuer) are expected to move from below and toward the 45 degree line over time and could eventually reach the area above it.

In Figure 3-1 for yen invoicing shares, there is not much sign that the use of the yen has risen over time for most economies. Korea and Thailand show a moderate increase in the yen share while the share of Japan as their export destination has been declining. Iceland is the only country that has approached the 45 degree line over time, but with a rapidly declining export share and a gradually declining currency share.

In Figure 3-2 for DM invoicing shares, Japan, Korea, and Italy show increases in both the DM invoicing share and the export share with Germany. Compared to the yen, many of Germany's partner economies appear to move toward the 45 degree line or parallel to it,

\footnotetext{
11 We must also note that after the introduction of the euro, trade invoicing data in the EU (not just in the Euro Area) economies are reported for trade with outside the EU or the Euro Area, which indicates that there is data discontinuity between the shares of "legacy currencies" and the euro.
} 
suggesting that the use of DM as an invoicing currency is more in line with partners' trade links with Germany. Not surprisingly, European partners appear to move closer to the 45 degree line than non-European partner economies, except the U.K. which has had high levels of pound invoicing over years.

Figure 3-3 for euro export invoicing shows somewhat different patterns. Many EuroArea partner economies have increased the euro share for export invoicing, moving toward the 45 degree line. Some economies, such as Bulgaria, Croatia, Lithuania, and Romania, have reached the territory above the 45 degree line; these Eastern European economies have used the euro as the major invoicing currency more than proportionally to their export shares with the Euro Area. ${ }^{12}$

Thus far, we have observed that the use of the DM for trade invoicing was backed by trade ties between Germany and its trading partners and was naturally high among European partners. In contrast, the Japanese yen was not, and is still not, widely used despite Asian economies' strong trade ties with Japan. The use of the U.S. dollar was undoubtedly prevalent globally and higher than what many economies' trade ties with the U.S. suggested.

Preliminary interpretations. One may wonder why the levels of international use as an invoicing currency differ so much among the U.S. dollar, the DM and the yen, particularly by partner economies. The dominant role of the U.S. dollar as an invoicing currency may be explained by several factors. First, the U.S. has been the largest trading nation for a long time and many of its trading partners have found it beneficial to use the dollar for invoicing trade. Second, there has been easy and open access to U.S. dollar financing, particularly for trade purposes, because of the development of deep, broad and liquid U.S.-dollar financial markets. Third, once the U.S. dollar is selected by many traders and investors for various types of international transactions, other traders find it beneficial to also use the dollar. Fourth, the formation of U.S. dollar zone economies, i.e., economies that use the dollar heavily for trade, investment, financial, or currency policy purposes, may have contributed to the expansion of U.S. dollar invoicing.

\footnotetext{
12 Ito, et al. (2015) show that while these Eastern European economies increased euro invoicing, they also increased euro weights in their implicit currency baskets as well as euro holdings as foreign exchange reserves. Bulgaria pegged lev to the euro in 2007. Lithuania joined the European Exchange Rate Mechanism (ERM) in 2004 and then the Euro Area in 2015.
} 
To better understand the difference between the DM and the yen in terms of trade invoicing, information compiled in Table 1 is useful. The table reveals that in Europe the share of home-currency invoicing was dominant, followed by those of DM invoicing and U.S. dollar invoicing, while in Asia and Oceania the share of U.S. dollar invoicing was far dominant than those of home-currency invoicing and yen invoicing. ${ }^{13}$ Economies in Asia-Oceania, in contrast, never had sizable home-currency invoicing (even in Japan) and mostly adopted U.S. dollar invoicing, followed distantly by yen or DM invoicing. Ito and Chinn (2015) show that the average U.S. dollar share in export invoicing among the Asian economies is as high as $90 \%$.

Another important factor for the higher use of the DM than for the yen as an invoicing currency is that Germany was surrounded by countries with per capita income levels relatively similar to, and as high as, Germany's, while Japan was not. Ito and Chinn (2015) find that countries with higher per capita income tend to have lower shares of U.S. dollar export invoicing and higher shares of invoicing exports in their own home currencies. When firms from such European countries also conduct intra-industry trade with each other, they tend to invoice their trade in their own currencies, including the DM. As the size of the German economy was the largest and with a stable value of the DM, many European firms naturally selected the DM for trade invoicing. This has been undoubtedly facilitated by deep economic integration in Europe, which was far more advanced than in Asia-Oceania, especially before the 1990s. Financial market integration among European countries and their currency stabilization against the DM may have also contributed to lower transactions costs in DM invoicing.

In contrast, the Asia-Oceania economies have relied heavily on the U.S. dollar rather than their own home currencies, which applies even to Japan to some extent. There are several reasons for this. First, Japan was surrounded by developing and emerging economies which had per capita income levels much lower than Japan's and were also U.S. dollar-zone economies. Second, even though Japan's trade links with these economies have expanded through the formation of regional supply chains, trade has been conducted in U.S. dollar. In addition, one of the main export markets for products from the Asian supply chain is the U.S. As Goldberg and Tille (2008) and Ito et al. (2010) argue, firms tend to price to market, i.e., invoice their exports in the importer's currency, the dollar, so as to protect their competitiveness in the destination

\footnotetext{
13 The dominance of home-currency invoicing in Europe is in line with the old literature on currency invoicing (Grassman 1973, Page 1977) which found that exporters' currencies tended to be used for intra-European trade while the U.S. dollar tended to be used even for Europe's exports to the U.S.
} 
market. ${ }^{14}$ Finally, Japan's large trading companies (known as sogoshosha) and multinational companies have developed strategies to minimize exchange risks when conducting trade in U.S. dollar. They have been pooling risks, marrying claims and liabilities, and borrowing and lending in foreign currencies, including the U.S. dollar, on a global scale, so that they have had no strong incentive to invoice trade in yen (see Kawai 1996).

\section{Empirical Analysis on the Determinants of Major Currency Shares for Trade Invoicing}

In this section, we empirically analyze the determinants of the shares of major currencies used for trade invoicing by using a panel of cross-country, time-series data. We first focus on the use of major currencies for trade invoicing from the perspective of non-major currency economies. This analysis allows us to investigate the conditions of partner economies that would affect the choice of a currency for trade invoicing. Then, we examine the issue from the perspective of major currency countries and investigate the conditions of these countries that would affect the share of their currencies in invoicing their own trade.

\subsection{Estimation Framework}

We conduct panel data analysis using the augmented Ito-Chinn dataset, encompassing 56 countries and the Euro Area (23 developed economies and 33 emerging economies) for the period from 1970 through 2014. In this analysis, we investigate not only the U.S. dollar, the Japanese yen and the DM, but also the French franc (FF), the Italian lira (IL), the Swiss franc (SF), and U.K. pound sterling (UKP), though data limitations reduce the number of countries included in the analysis and make the panel highly unbalanced.

Our specification on the share of a specific major currency for export or import invoicing is:

$$
\lambda_{T R i t}^{C}=\beta_{1}^{C}+\beta_{2}^{C} X_{i t}^{C}+\beta_{3}^{C} D_{i t}+u_{i}^{C}+\varepsilon_{i t}^{C} .
$$

Here, $\lambda_{T R i t}^{C}$ is the share of major currency $C$ (either one of the U.S. dollar, yen, DM, FF, $\mathrm{IL}, \mathrm{SW}$, or UKP) used for invoicing exports from or imports to (i.e., $T R=E X$ or $I M$ ) country $i$ in

\footnotetext{
${ }^{14}$ Takagi (2009) argues that established practices of pricing and invoicing trade in U.S. dollar in Asia hampered the internationalization efforts of the Republic of Korea's won despite the country's increased presence as a major exporter.
} 
year $t$. Vector $X_{i t}^{C}$ represents the fundamental economic factors of country $i$, including the share of country i's export to, or import from, the country that issues the major currency (e.g., the share of country $i$ 's exports to, or imports from, Japan for the yen share estimation); the share of country $i$ 's commodity trade in total exports or imports; country $i$ 's per capita income level relative to the U.S.; country $i$ 's exchange rate volatility and inflation differentials vis-à-vis the respective major currency country; the degree of country $i$ 's financial development; and the degree of country $i$ 's financial openness. ${ }^{15}$ Vector $D_{i t}^{C}$ represents dummy variables, including those for: currency arrangements, such as pegs to the U.S. dollar and the DM; EU membership; the Bretton Woods period $(B W)$, which takes the value of one for all years after 1973 and zero otherwise; and former colonies of either the U.K. or France.

We repeat the same estimation exercise for each major currency $C$. Because estimation equation (1) attempts to identify the determinants of the use of a major currency for trade invoicing by sample economies, we do not include data for the major currency country in each panel data. For example, German economic fundamentals are not included in the estimation equation of the DM share. For comparison purposes, we restrict the sample period for all the major currencies to the period 1970 through 1998, the year before the introduction of the euro. ${ }^{16}$

In equation (1), $u_{i}$ is a random error attributable to country $i$ and $\varepsilon_{i t}^{C}$ is a white noise residual. Testing for a zero variance of the error terms with the Breusch-Pagan Lagrange Multiplier suggests that the panel cannot be pooled for every estimation (i.e., the null hypothesis of zero variance of the individual errors is rejected). The panel structure of the dataset suggests that the estimation exercise should account for potential unobservable country effects. However, it is not clear whether unobservable country effects are systematic (i.e., correlated with predictors), which would require estimation with fixed effects, or non-systematic, which would require random effects. Hausman tests yield mixed results depending on the sample, which must be partly due to the unbalanced panels and sometimes small sample sizes. Hence, we report the results for estimations with both random and fixed effects. In addition, we also conduct PraisWinston estimation with panel corrected standard errors that controls for possible heteroscedasticity across the panel. For this exercise, we estimate with weights based on the

\footnotetext{
${ }^{15}$ For data definitions, refer to Data Appendix.

${ }^{16}$ However, again, the sample period can differ depending on data availability. See the notes below the estimation results tables.
} 
share of GDP in world GDP (in PPP) as our sample economies are highly diverse in terms of economic size.

The choice of explanatory variables for fundamental economic factors is based on the past literature on trade invoicing. Below, we briefly discuss the theoretical rationales for testing the variables as well as our expectations for the signs of the estimated coefficients of the variables. $^{17}$

Trade ties vis-à-vis a major currency country. Firms tend to invoice their exports in the currency of a major-currency country to minimize the fluctuations of their local currency prices relative to those of competitors'. Such a "coalescing effect" (Goldberg and Tille, 2008) can result in the positive effect of country $i$ 's export share with a major-currency country on the major currency share in country $i$ 's export invoicing. Also, Goldberg and Tille (2005) argue that producers in industries with high demand elasticities (e.g., homogenous goods) tend to "herd" in their choice of an invoicing currency to maintain stable prices relative to their competitors'. Thus, we expect a positive coefficient for this variable. ${ }^{18}$

Commodity trade as a percentage of total trade. Commodities are almost exclusively denominated in the U.S. dollar. McKinnon (1979) predicted that homogenous goods tended to be invoiced in a single, low transaction cost currency, such as the U.S. dollar. His prediction leads to the expectation that the estimated coefficient on the share of commodity exports is positive for the U.S. dollar and negative for the other major currencies.

Relative income. The "coalescing effects" in Goldberg and Tille (2008) also mean that the more differentiated goods an economy exports, the more likely it is to invoice its exports in its home currency. ${ }^{19}$ Manufacturers of highly differentiated products may have bargaining power in the market, exploit scale economies, and thus invoice exports in their own home currency instead of major currencies. We use an economy's per capita income relative to that of

\footnotetext{
17 Our explanations mainly focus on the behavior of export invoicing. Broadly speaking, theoretical predictions of export invoicing are mostly applicable to those of import invoicing.

18 The literature on trade invoicing overlaps the one on exchange rate pass-through as the choice of an invoicing currency is related to the decision of producer currency pricing or local currency pricing (Kamps, 2006). Sasaki (2002) compares the patterns of exchange rate pass-through of Japanese exports in the U.S., Asian, and EU markets and finds that the price-to-market elasticity is the highest for Japanese exports to the U.S. market. She attributes this result to a high degree of competition in the U.S. market.

19 Tavlas (1991) finds with German trade invoicing data that producers tend to price their products in their own currency when products are differentiated. Oi, et al. (2004) argue that the yen is more often used in industries with differentiated products like the automobile industry.
} 
the U.S. as a proxy for the economy's capacity to produce differentiated products. Thus, the expected sign of the estimated coefficient is negative for the U.S. dollar, the DM and the yen.

Exchange rate volatility and inflation differentials. When an economy's macroeconomic conditions are unstable, such as with volatile exchange rates and high inflation, major currencies rather than its home currency are likely to be used for trade invoicing. Tavlas (1997) attributed the high DM use for both import and export invoicing in Europe to the stability of the DM value, backed by Germany's stable monetary policy. The implication was that a European economy with high inflation rates tended to use the DM, rather than its home currency, for trade invoicing. Similarly an economy with high exchange rate volatility would use one of the major currencies for trade invoicing. ${ }^{20}$ Inflation rate differentials are calculated as the differences in the annual rates of CPI inflation between the sample country and major-currency countries. Exchange rate volatility is calculated as annual standard deviations of the monthly rates of change in the exchange rate against the currency of the major currency of concern.

Financial development. An economy with a large, liquid, and deep financial market tends to face low transaction costs in using its own currency and therefore use it for trade invoicing. This leads to the prediction that an economy with a more developed and larger financial market tends to invoice its trade in its own home currency. However, if the economy's financial market is developed but relatively small, it may choose to use a major currency for trade invoicing because doing so would entail a low transactions cost for trade invoicing or settlements. To examine the impact of financial development on currency invoicing, we define a variable for "financial development" as the product of private credit creation (as a share of GDP) and the relative size of private credit creation of country $i$ in the world's total private credit creation. Since the level of financial development in each economy relative to that of the major currency country matters, we further adjust the variable as a deviation from the level of a major currency country. We expect a negative impact of this variable.

Financial openness. An economy with an open financial market tends to invoice its trade in its home currency because such a currency could provide more usability and convenience for international investors, suggesting a negative coefficient for the financial openness variable in the equation for the major currency share. However, greater financial

${ }^{20}$ Donnefeld and Zilcha (1991) present a theoretical model that predicts greater invoicing in the importer's currency (LCP) and lesser invoicing in the exporter's or third country's currency under higher exchange rate risks. Donnefeld and Haug (2003) provide empirical evidence to support such predictions. 
openness could also make it easier for traders to invoice in a major currency. Hence, the impact of financial openness on the shares of major currencies can be negative or positive. For the measure of capital account openness, we use the Chinn-Ito index of capital account openness (Chinn and Ito, 2006, 2008, and updates). Similarly to the financial development variable, we adjust the financial openness index as a deviation from the level of the major currency country.

Dummies for exchange rate arrangement, monetary union and former colonies. When an economy pegs its currency to a major currency such as the U.S. dollar and the DM, we expect the economy to invoice its trade in the major currency. Also, Bacchetta and van Wincoop (2005) show that the currency of a monetary union tends to be used extensively for trade invoicing by member countries, possibly due to the economies of scale. The current EU members, whether they are members of the Euro Area or not, had close relationships with the DM either through the European Exchange Rate Mechanism (ERM) or simple geographical proximity. Thus the U.S. dollar-peg dummy is expected have a positive effect on the U.S. dollar invoicing share and a negative effect on the other currency shares. The EU membership dummy is expected to have a positive effect on the DM invoicing share and a negative impact on the U.S. dollar or yen invoicing share. $^{21}$

Similarly, economies often have closer trade and financial relationships with their former colonizers. Hence, we include the dummies for former British and French colonies.

\subsection{Estimation Results on the Determinants of Major Currency Shares for Trade Invoicing by Non-Major Currency Economies}

We run regression equation (1) for each of the seven major currencies, the U.S. dollar, yen, DM, FF, IL, SF and UKP. In this part of the analysis, we examine how conditions in our sample countries, excluding these seven major-currency countries, affect the use of major currencies for trade invoicing.

\footnotetext{
21 The countries in the EU subsample are: Austria, Belgium, Bulgaria, Cyprus, Czech Republic, Denmark, Estonia, Finland, France, Germany, Greece, Hungary, Ireland, Italy, Latvia, Lithuania, Luxembourg, Malta, Netherlands, Poland, Portugal, Romania, Slovak Republic, Slovenia, Spain, Sweden, and the United Kingdom. The dummy for the EU membership is assigned for the entire sample period regardless of the year of entry to the union, i.e., timeinvariant. The inclusion of this dummy is based on stylized facts that the invoicing behavior would differ for EU member countries even before they actually become the members, partly because of the existence of precursor organization such as the European Community and also of geographical reasons for other countries that did not participate in the precursor organizations (such as former communist states). We follow Kamps (2006) on this.
} 
Table 2-1 reports the estimation results on the shares of the U.S. dollar, the yen, the DM, while Table 2-2 reports the results for the FF, IL, SF and UKP. For each currency, we use three specifications: first with random effects, second with fixed effects, and third with panel corrected standard errors (PCSE) to control for possible heteroscedasticity across the panel. These different specifications yield similar results. While Tables 2-1 and 2-2 report the results for export invoicing, Table 3 reports the results for import invoicing in the U.S. dollar, yen and DM, though we will focus our discussions mainly on the results of the estimations for export invoicing. ${ }^{22}$

First of all, for both the yen and the DM, we find that the export market share matters. The larger the share of an economy's export to Japan or Germany in its total exports is, the more likely the exports tend to be invoiced in the yen or the DM. The effect of the export share on the currency share is much larger for the DM than for the yen. Given the long tradition of trade integration in Europe, this result is unsurprising. Trade integration in Asia, especially in the sample period, was not as deep as in Europe, as reflected in the low level of yen invoicing by third economies. Interestingly, the effect of trade links with the U.S. on U.S. dollar invoicing is mixed. The estimate of a third economy's export share is significantly negative in the fixed effects model while it is insignificantly positive in the random effects and the PCSE models.

When we compare the results with those of other major currencies in Table 2-2, we can rank the seven major currencies in terms of the magnitude of sensitivity to the export share as the DM, Swiss franc, and U.K. pound being the most sensitive, followed by the French franc, Italian lira, yen, and dollar. ${ }^{23}$

Second, an economy with a large value of commodity exports tends to invoice export less in a major currency. However, the estimation results for import invoicing, which is more relevant for many of our sample economies which are commodity importers, show that the commodity import share has a significantly positive effect on the U.S. dollar share across the three models. The estimated coefficient of 0.47-0.57 for the U.S. dollar equation is considerably larger than those for other major currencies, confirming that the dollar has been playing a dominant invoicing-currency role in commodity markets.

\footnotetext{
22 The variables for export/import share, exchange rate volatility, inflation differential, financial development and financial openness are altered depending on which major currency is being estimated.

${ }^{23}$ The results of the estimations on import invoicing (Appendix Table 2) show that the effect of trade linkages with the U.S. and Germany is larger in magnitude. Interestingly, while the import share matters for the U.S. dollar, the import share does not. For the yen, the share of import from Japan does not matter. For the DM, the elasticity is high at around one.
} 
Third, an economy with higher inflation tends to invoice its export more in the U.S. dollar or the DM and less in the yen. An economy with larger exchange rate volatility tends to invoice its export in the DM, suggesting that an economy with unstable macroeconomic conditions tends to view the DM or the dollar as an appropriate invoicing currency.

Fourth, an economy with a deeper and larger financial market or a more open financial market is less likely to invoice its export in the U.S. dollar or yen. Such a tendency is not observed for the DM. ${ }^{24}$ The negative impact of financial development or openness on the majorcurrency share may suggest that an economy with a more developed or more open financial market tends to invoice more of its export in its own home currency, thereby leading to lesser use of major currencies for trade invoicing (Ito and Chinn, 2015).

Finally, an economy with its currency pegged to the U.S. dollar does not seem to invoice in the U.S. dollar in a statistically significant manner, while such an economy tends to invoice its export less in the yen. Interestingly, an economy with a DM peg tends to invoice its export more in the U.S. dollar and only weakly in the DM. These binary variables may not fully capture the subtlety of the link between the sample economies and the U.S. dollar. We will investigate this issue more carefully in a later subsection.

\subsection{Effects of Industrial Structure}

The choice of a currency for trade invoicing tends to be affected by the level of bargaining power of traders (i.e., exporters or importers) as we previously described. McKinnon (1979) focused on the importance of product differentiation on the choice of invoicing currency. He argued that exporters from European industrialized countries tended to price their products in their home currencies because they tended to export differentiated manufactured goods. Conversely, exporters of relatively homogeneous primary goods tended to price their products in the U.S. dollar as the dollar tended to be a dominant currency in commodity markets.

\footnotetext{
${ }^{24}$ When we include country $i$ 's private credit creation as a share of its GDP (credit depth) and country $i$ 's private credit creation as a share of the world's total (relative credit size) individually, in the U.S. dollar and the UK pound share equations, only the relative credit size is found to have a negative coefficient. In the French franc and the yen share equations, only credit depth turns out to have significant negative coefficient. In the Swiss franc share equation, credit depth has a positive coefficient while the relative credit size has a negative coefficient. These findings suggest that the relative credit size matters more for certain currencies while credit depth matters more for others.
} 
Goldberg and Tille (2008) in their seminal paper argued that when the demand elasticity is high, or there are competitive substitutes in the export destination market, exporters tend to price their products in the export market's currency so that they can limit the fluctuations of their prices relative to those of the competitors' goods - the so-called "coalescing effect." Bacchetta and Van Wincoop (2005) used a general equilibrium model and showed that exporters who have higher market shares in the export market or who export differentiated products tend to invoice exports in their own currency.

Although we have already included the relative income variable as a proxy to measure the extent of export product differentiation, we are also aware that this proxy may not be appropriate or sufficient. Hence, we test several other variables that should represent the abilities of the sample economies to produce and export differentiated products. ${ }^{25}$

We use the following two types of variables as a proxy for product differentiation, i.e., the share of manufactured goods in total exports and the share of imports from country $i$ in the total imports of major currency country $C$. The first variable is not the best proxy for product differentiation because manufactured goods are not always differentiated goods, but we still test this variable. The second variable attempts to capture the market share of country $i$ 's exports in the export market (i.e., major currency country $C$ ) and, thus, bargaining power of exporters which can come from product differentiation as well as market shares. We include both variables in our baseline model (with the random effects), and expect a negative coefficient for both. Our prior is that the more differentiated goods a country exports, or the more market power it has in the major-currency country, the more likely it is to use its home currency and, thus, the less likely to rely on a major currency for trade invoicing.

When we test the first variable, i.e., the share of manufactured goods in exports, we obtain mixed results while the effects of other variables remain intact (not reported). This is not surprising considering that the manufactured export share is only a weak proxy for product differentiation. Specifically, for the estimations on the shares of the yen and the franc, we find a significantly negative estimate on the manufacturing goods share variable while for British

\footnotetext{
${ }^{25}$ Although James Rauch's (1999) product differentiation index would be appropriate for this purpose, we cannot use this index unless detailed industrial structure or composition is identified for each of our sample economies, which would be beyond the scope of this paper.
} 
pound and the Swiss franc, we find a significantly positive estimate, and for the Italian lira, the U.S. dollar, and the DM, we find insignificant estimates. ${ }^{26}$

The results from estimations with the second variable, i.e., the market share in the majorcurrency country, are similarly mixed. The estimated coefficient on the variable is significantly negative for the Swiss franc and the U.S. dollar and marginally negative for pound sterling and the DM, while it is significantly positive for the yen. The results from the dollar equation are the most interesting, however, because the market share has not only a significantly negative coefficient but also it's a large magnitude in absolute value; a one percentage point increase in the market share of imports to the U.S. from country $i$ leads to a 0.87 to 1.48 percentage decrease in the dollar share in export invoicing. ${ }^{27}$ At least, it appears that market power allows a country to reduce its reliance on dollar invoicing, or to a lesser extent, on invoicing in other major currencies such as the Swiss franc, pound sterling, and the DM. For this type of analysis, estimations with industry-level or firm-level data would be more appropriate. We keep it as one of our future research agendas.

\subsection{Effects of Trade Shares with Major-Currency Zone}

In the above analysis, we have considered the effect of a non-major currency economy's exchange rate arrangement on the use of major currencies for trade invoicing. In so doing, we have included dummies for a U.S.-dollar peg and a DM-peg. We now extend the analysis and deal with this issue in a more nuanced way.

When an economy pegs its own currency to a major currency, such as the U.S. dollar and the DM, it is expected to invoice its export in the major currency chosen. However, the dummies in the previous regression analysis may not capture the effects of different degrees of pegs to major currencies.

An economy adopting a G5-currency basket system, say, $a \%$ to the U.S. dollar, $b \%$ to the $\mathrm{DM}, c \%$ to the French franc, $d \%$ to U.K. pound, and $e \%$ to the yen can be hypothesized to follow a currency invoicing pattern which is proportional to the basket weights. These currency weights

\footnotetext{
${ }^{26}$ In the case of the yen, the adjusted R-sq. increases significantly when the manufacturing export share variable is included (from $65 \%$ to $82 \%$ ).

27 The estimate on the share of exports bound for the U.S. in total exports of country $i$ (i.e., $\frac{E X_{C \leftarrow i}}{E X_{i}}$ ), which was insignificant in Table 2 becomes significantly positive.
} 
can be separately estimated for each economy for each year, using the widely-used method developed by Haldane and Hall (1991) and Frankel and Wei (1996). With the estimated weights, we can test whether and to what extent the weights of currencies in the basket affect the share of major currencies for trade invoicing.

Constructing G5-currency weights and G5-currency zones. We can go one step further by considering the possibility that an economy trading heavily with, say, the "U.S. dollar zone" countries sets the U.S. dollar share for trade invoicing at a high level even though its direct trade link with the U.S. is limited. Similarly an economy trading heavily with the DM (or yen) zone countries may set a high share for DM (or yen) invoicing. For each non-major currency economy (say Thailand), we can estimate the size of its trade with major-currency zone countries. To do so, we take a two-step procedure, assuming that there are five major currencies, i.e., the U.S. dollar, DM, yen, FF and UKP. ${ }^{28}$

First, we run the following estimation model:

$$
\Delta e_{i t}^{U S D}=\alpha_{i}+\beta_{i J Y t} \Delta e_{i t}^{J Y}+\beta_{i B P t} \Delta e_{i t}^{U K P}+\beta_{i D M t} \Delta e_{i t}^{D M}+\beta_{i F F t} \Delta e_{i t}^{F F}+\varepsilon_{i t} .
$$

Here, $e_{i t}$ is the nominal exchange rate of home currency $i$, against the dollar (USD), yen (JP), pound (UKP), Deutsche mark (DM), and French franc (FF). The major currencies in the righthand side of the estimation equation can be thought of comprising an implicit currency basket in the mind of the home economy's policymaker. Therefore, $\hat{\beta}_{i h}$, the estimated coefficient on the rate of change in the exchange rate of major currency $h$, represents the weight of currency $h$ in the implicit basket. The weight of the dollar can be calculated as $\hat{\beta}_{i U S t}=1-\left(\hat{\beta}_{i J Y t}+\hat{\beta}_{i B P t}+\hat{\beta}_{i D M t}+\hat{\beta}_{i F F t}\right){ }^{29} \mathrm{We}$ apply the estimation model to each of our sample currencies, but estimate it over rolling windows of 36 months. Hence, the coefficients $\hat{\beta}_{i h}$ 's are time-varying in monthly frequency to reflect the assumption that policymakers keep updating their information sets and, thus, currency weights. This rolling regression is not run for the G5

\footnotetext{
28 These are the original five currencies that used to be included in the IMF's SDR. The DM and FF were replaced by the euro in 1999 .

${ }^{29}$ If the home currency is pegged to the U.S. dollar (e.g., Hong Kong dollar), then $\hat{\beta}_{i U S t}=1$ and $\sum_{\substack{h=1 \\ h \neq U S}}^{H} \hat{\beta}_{i h}=0$. For an economy with its currency pegged to the DM, $\hat{\beta}_{i D M t}=1$.
} 
currencies, but their currency weights are set at the value of one, that is, each of the G5 countries is assumed to constitute its own currency zone without depending on other major-currency exchange rates.

Next, using the estimated currency weights, we can divide the trade partners of each nonmajor currency economy into five currency zones. To do so, every non-G5 economy is divided into G5-currency zones, based on the estimated G5-currency weights, i.e., $\hat{\beta}_{i h t}$, for the economy. For example, if Thailand has a currency basket, with the USD weight of $a \%$, the DM weight of $b \%$, the FF weight of $c \%$, the BP weight of $d \%$, and the yen weight of $e \%$, then we assume that $a \%$ of Thailand's economy belongs to the USD zone, $b \%$ to the DM zone, $c \%$ to the FF zone, $d \%$ to the UKP zone, and $e \%$ to the yen zone. All other non-G5 economies are similarly divided into G5 currency zones. On the other hand, each of major currency countries is assumed to constitute its own currency zone. Then, the trade share of a non-G5 economy (say India) with countries belonging to a major-currency zone can be calculated first by multiplying $\hat{\beta}_{i h t}$ with bilateral trade with each partner (say Thailand, so bilateral trade between India and Thailand is defined as the sum of bilateral exports and imports), and then by summing up all the products over all the bilateral trade pairs. The ratio of this sum to the economy's (India's) total trade is regarded as its trade share with one of the "major-currency zones." 30

The hypothesis we test here is that the share of a major currency for trade invoicing used by non-major currency economies is explained by: (1) the estimated weights of G5 currencies in the implicit baskets of these economies and (2) the share of these economies' trade with the major-currency zone countries. We test the hypothesis for the U.S. dollar, the DM, and the yen. Because of the way the currency weight of the U.S. dollar is calculated and also of the possibility of multicollinearity among trade shares with major-currency zone countries, we will include only one of the major-currency weights or one of the trade shares with major-currency zone countries at a time in the estimation.

Estimated G5-currency weights and zones in Europe and Asia-Oceania. Before discussing the estimation results, we present some interesting stylized facts regarding the

\footnotetext{
30 For country $i$, the currency zone share for major currency $h$ is $S H A R E_{-} h_{i t}=\frac{\sum_{j}^{J} \beta_{j h t} \cdot T R A D E_{i j t}}{T R A D E_{i t}}$ where $j$ is $i$ 's
} trading partner $(j \in J)$ and $\sum_{h}^{H} S H A R E_{-} h_{i t}=1$. 
estimated currency weights in Table 4. Panel (a) of the table reports the estimated weights of the U.S. dollar, the DM and the FF combined (or the euro after its introduction), U.K. pound, and the yen for European countries for the period 1972-2012 while Panel (b) reports the same pieces of information for Asia-Oceania countries. ${ }^{31}$

For European countries, the DM-FF weight is close to or above $90 \%$ after the 1980 s although the U.S dollar weight was high in 1972, a year before the collapse of the Bretton Woods system. The high values of the DM-FF weight must have led to a smooth transition to the Euro Area in 1999. All Asia-Oceania countries, except for India, have virtually belonged to the U.S. dollar zone. India used to belong to the U.K pound zone until the end of the 1980s, but it has since switched to the U.S. dollar zone. European countries largely belonged to the DM zone, which must have contributed to high DM shares for trade invoicing, while Asia-Oceania countries belonged mostly to the U.S. dollar zone rather than the yen zone.

Table 5 presents the shares of trade with each of the four currency zones in Europe and Asia-Oceania. The table illustrates a picture consistent with the previous table. European countries such as Belgium, Denmark, Italy and Netherlands, traded heavily with the DM-FF (EURO) zone with the share of 40-70\% at least from the late 1970s, while France, Germany and the U.K. which used to trade more with U.S. dollar zone countries (with the share of 40-60\%) in the 1970s shifted to trade more with DM zone countries in the late 1980s. Asia-Oceania countries traded heavily with U.S. dollar zone countries. In fact, Japan had the highest share of dollar zone trade of as high as 70-76\%. Indonesia used to have higher shares of trade with yen zone countries than with dollar zone countries in the 1970s, and Korea and Thailand also had high trade shares with yen zone countries. However, their yen shares have declined steadily and given way to the U.S. dollar zone countries over time.

Effects of G5-currency weights and zone. Now, Table 6 summarizes the results from the estimations that test the importance of the estimated weights of the U.S. dollar, yen, or DM as well as the trade share with the major-currency zones in determining the major currency shares for trade invoicing. The table only reports the estimated coefficients on the currency weight or the currency-zone trade share for simplifying the presentation. ${ }^{32}$

31 The home currency weight is assumed to be $100 \%$ for each of G5 countries.

32 The estimates on the other variables are generally unaffected. 
According to the table, an economy with a higher dollar weight tends to invoice its export more in the dollar and less in the DM, though its impact on the dollar share is statistically insignificant. The dollar weight does not affect the yen share. An economy with a higher DM weight tends to invoice its export more in the DM, though the impacts on dollar or yen invoicing is insignificant. Finally, an economy with a higher yen weight tends to invoice its export more in the DM, a somewhat puzzling result. Generally, the signs of the estimates indicate that the U.S. dollar and the DM are in a competitive relationship while yen invoicing is not much affected by either any of the major-currency weight.

The bottom half of the table shows that an economy with a higher trade share with dollar zone countries tends to invoice its exports more in the dollar and less in the DM or yen. An economy with a higher trade share with DM zone countries tends to invoice its trade less in the dollar, though not exhibiting significant impact on DM or yen invoicing. Finally, an economy with a higher trade share with yen zone countries tends to invoice its trade less in the yen or the dollar, with no significant impact on DM invoicing. Considering that trading more with dollarzone countries would lead to a lower share of DM invoicing, and that trading more with DMzone countries would lead to a lower share of dollar invoicing, the U.S. dollar and the DM arer in a competitive relationship. The negative effect of the yen-zone trade share on yen invoicing, a puzzling result, appears to reflect that yen invoicing continued to decline despite the fact that countries in Asia-Oceania (e.g., Korea, Thailand) strengthened their trade ties with Japan in the 1970 s-90s. ${ }^{33}$

\subsection{Differences among the Major Currencies in Terms of the Determinants of Trade}

\section{Invoicing}

As the previous analysis has demonstrated, the way in which the conditions of non-major currency economies affect the use of major currencies for trade invoicing differs among the currencies, not to mention among the big three: the U.S. dollar, yen, and DM.

We now formally test to examine whether the seven major currencies (the U.S. dollar, yen, DM, U.K. pound, French franc, Italian lira, and Swiss franc) are used differently for trade invoicing from each other. We estimate an extended version of equation (1) by lumping together

\footnotetext{
33 This may be explained by a rapidly increasing dollar weight that occurred to Japan's trading partners in the sample period, some of which are depicted in Table 5.
} 
all the observations, i.e., invoicing shares for the seven major currencies on the left-hand side and the corresponding data on the right-hand side variables of the equation. We run the following regression equation:

$$
\lambda_{T R i t}=\beta_{1}+\beta_{2} X_{i t}+\beta_{3} D_{i t}+\phi_{1} C D^{C}+\phi_{2} X_{i t} \cdot C D^{C}+u_{i}^{C}+\varepsilon_{i t}^{C} .
$$

Here, $\lambda_{\text {TRit }}$ is the share of any one of the seven major currencies, and $C D^{C}$ is the currency dummy for each of the major currencies. We run this estimation model with each of the seven currency dummies individually and test if $\phi_{1}$ and $\phi_{2}$ are jointly significantly different from zero. If the null hypothesis of $\phi_{1}$ and $\phi_{2}$ being jointly equal to zero is rejected for currency $C$, that means the way the determinants affect the share of currency $C$ in export invoicing is significantly different from that of the other major currencies. We use the Chi square statistics to test the joint significance.

Tests of similarity of the determinants of major-currency shares. Table 7 reports the Chi squares and the corresponding $p$-values for the joint testing of $\phi^{\prime} s$ being zero. For example, the first row of the first column shows the result of testing the null hypothesis that the way economic fundamentals affect the share of U.S. dollar for export invoicing is no different from those affecting the other six major-currency shares. The second column reports the result of testing if the null that the determinants of the yen share are no different from those of the other sixcurrency shares. The other columns toward the right show the results from testing the similarity of the determinants of the DM share, and so forth.

When we test each of the seven currencies, the null hypothesis is rejected for the U.S. dollar, the yen, and the DM. The Chi square is overwhelmingly high and statistically significant for the U.S. dollar invoicing share, suggesting that the determinants of the dollar share differ distinctly from those of the other six currencies. We then remove the data relevant to the U.S. dollar invoicing share from the sample and test the similarity of the remaining six currencies. The second row of the table reports that the yen is different from the other five currencies, followed by the DM, UKP, FF, IL, and SF. When we remove the yen invoicing share data and test among the five currencies, we find that the DM is different from the other four currencies.

These findings indicate that the U.S. dollar, the yen, and the DM behave most differently among the seven major currencies in terms of the determinants of the currency shares for export invoicing while the U.S. dollar is clearly an outlier with its significantly high Chi square. 
Differences among the U.S. dollar, yen and DM. Now that we find that the U.S. dollar, the yen, and the DM are distinct invoicing currencies, we next examine how they differ from other currencies.

Table 8 reports the results from estimations based on equation (3). The first column reports the result for the estimation of major-currency shares with the dollar dummy interacted with the economic fundamentals as we did in the first round of test in Table 7. First, we observe that compared to the other six major currencies, the U.S. dollar share for export invoicing is highly responsive to the export share with the U.S. While a one percentage point increase in the export share with the six major-currency countries would lead to a 0.502 percentage point increase in the major-currency invoicing share on average, the same increase would lead to a $0.953(=0.502+0.451)$ percentage point increase in the U.S.-dollar invoicing share, much higher compared to the other six currencies. Second, while the commodity export share has no significant impact on the invoicing shares of six major currencies on average, a one percentage point increase in the commodity export share would lead to a 0.387 percentage point increase in the dollar invoicing share. Third, an economy with higher per capita income tends to invoice its export more on average among the ex-dollar major currencies (with the estimated coefficient of 0.122), but less in the U.S. dollar in the presence of the U.S. dummy interacted with per capita income $(-0.531=0.122-0.653)$. Fourth, greater financial development in non-major currency economies has a positive impact on the average invoicing share of the six major currencies (with the estimate of 0.052), but it has a negative impact on the share of U.S. dollar invoicing $(-0.058=$ 0.052-0.110). This suggests that economies with more developed financial markets tend to diversify trade invoicing currencies away from the U.S. dollar and toward other major currencies. Fifth, financial openness in non-major currency economies has a negative impact on the invoicing shares of all the major currencies and this negative impact is even larger on U.S.dollar invoicing. Thus, economies with more open financial markets tend to reduce the use of major currencies, particularly the U.S. dollar, for export invoicing. Sixth, a rise in the trade share with dollar zone countries negatively affect the average share of ex-dollar major currencies ($0.120)$, while it positively affects the dollar invoicing share with the estimate of $0.640(=0.760$ 0.120). Finally, the U.S. dollar dummy is statistically significant and positive with the estimated value of 0.196, which suggests that the U.S. dollar share is higher than the other six currencies 
by almost $20 \%$ for some intrinsic characteristics of the dollar unexplained by the estimation model.

The second column of Table 8 reports the estimation result for the average invoicing share for six major currencies, excluding the U.S. dollar, with the yen dummy interacted with the economic fundamentals. It shows that yen invoicing differs from the invoicing of the other five currencies.

The yen share for export invoicing is much less responsive to the share of non-major currency economies' export to Japan than to the other five major currencies (0.182 vs. 0.683$)$. The yen invoicing share is negatively affected by the share of other economies' commodity export unlike the other major-currency invoicing shares. While a higher level of per capita income does not lead to a higher invoicing share for the ex-yen five major currencies on average, it leads to a higher yen invoicing share. The high rate of inflation in a non-major currency economy does not affect the invoicing share of the ex-yen major currencies, but it reduces the yen invoicing share (with the estimate of -0.068). Among the six major currencies, financial development in a non-major currency economy has a negative impact only on yen invoicing (with the estimate of -0.077). As in the case with the dollar invoicing share, financial openness has a negative impact on major-currency invoicing and this negative impact is more pronounced on yen invoicing. The trade share with U.S.-dollar zone countries has no significant impact on the ex-yen major-currency invoicing share, but it positively affects the yen invoicing share, a somewhat unintuitive result though the magnitude is relatively small. ${ }^{34}$ The yen dummy is negative, suggesting that the yen invoicing share is lower than those of the other five major currencies by almost $3 \%$ due to its own intrinsic characteristics unexplained by the model.

The third column of the table reports how the behavior of DM invoicing differs from the other four major currencies, excluding the U.S. dollar and the yen. Determinants of the DM invoicing share do not differ much from those of the other major currencies; only commodity trade and the trade share with dollar-zone economies behave differently from the other major currencies. Like the yen invoicing share, the DM invoicing share negatively responds to the share of commodity export. Unlike the yen, however, the trade share with U.S.-dollar zone countries lowers the DM invoicing share. The DM dummy suggests that there is still a 9

\footnotetext{
34 This result is consistent with the negative impact of the trade share with yen zone countries on the yen invoicing
} share, which we saw in Table 6. 
percentage point advantage to the DM share over the remaining four European currencies due to its own intrinsic characteristics unexplained by the model.

\subsection{Conditions in Major Currency Countries as the Determinants of Major Currency Shares for Trade Invoicing}

Thus far, we have examined how economic fundamentals in non-major currency countries affect the use of major currencies for trade invoicing in the 1970s through the 1990s. We now turn our attention to how the economic fundamentals of the major currency countries affect the use of their own currencies for trade invoicing (e.g., the use of the yen by Japan, the DM by Germany, etc.).

We now estimate the model based on equation (1) by using a panel data for major currency countries, excluding the U.S. (i.e., Japan, Germany, U.K., France, Italy and Switzerland). The estimation is basically that of home-currency invoicing as we use only majorcurrency country data. We exclude U.S. data because of the exceptionally distinctive behavior of U.S. dollar invoicing as we saw in Tables 7 and $8 .^{35}$

The estimation results are reported in Table 9. The results shown in columns (1) and (3) of the table reveal that a major currency country, excluding the U.S., tends to invoice in its exports or imports more in its home currency when the country is a larger exporter or importer (in terms of the share in the world export or import), or when its per capita income is higher. A major-currency country with a large commodity export share tends to invoice its exports in its own currency, while a large commodity importer tends not to invoice its imports in its own currency. The finding on export invoicing appears counterintuitive, but the positive effect reflects mainly the behavior of France and the U.K., both of which are large commodity exporters among the six major-currency countries. ${ }^{36}$ A major-currency country with a developed financial market tends not to invoice its exports or imports in its home currency, but a majorcurrency country with an open financial market tends to invoice its exports, but not imports, in

\footnotetext{
35 Following work by Ito and Chinn (2015) which finds that economic fundamentals in a country affect the use of its "home currency" for a number of countries in 1970-2013, we do the same but only with the sample of the major currency countries, but excluding the U.S.

36 In fact, when the model is run with fixed effects, the significantly positive estimate on the share of commodity export disappears, suggesting that the positive estimate reflects country differences, which we assume to be France and the U.K., based on the scatter diagram that depicts the home-currency invoicing share against the share of commodity export (not reported).
} 
its own currency. While the positive impact of financial openness on home-currency invoicing is intuitively plausible, the negative impact of financial development is somewhat puzzling. For import invoicing, financial openness has no significant impact while financial development has significantly negative impact which is also somewhat puzzling. A major-currency country with a high trade share with U.S.-dollar zone countries tends not to invoice its exports and imports in its own currency, which most likely implies that such a country tends to invoice its trade in the U.S dollar.

The puzzling negative impact of financial development on home-currency invoicing can be resolved to some extent by including an interactive term between financial development and financial openness, as reported in columns (2) and (4) of Table 9. A major-currency country tends to invoice its exports less in its own home currency if it only has a developed financial market, but the negative effect of having a more developed financial market can be mitigated by opening the financial market more for cross-border transactions. The financial market openness variable and the interactive term have positive impacts on home currency invoicing, and significantly so in export invoicing, for major currency countries. The estimated coefficients reported in column (2) suggest that if the degree of financial market openness is sufficiently high, that is, if it is greater than 0.5 , then the impact of financial development on home currency invoicing for export is positive. These results indicate that when the financial markets of major currency countries are more developed, but if they have a limited degree of financial market openness, they tend to see less of home currency invoicing. However, if they have a sufficiently open financial market, they tend to see more of home currency invoicing.

It must be noted, however, that the interaction effect of financial development and openness disappears when we remove Japan from the sample. In other words, the interaction effect seems Japan-specific. Nonetheless, considering that Japan rose from a small financial power to a global powerhouse by the latter half of the 1980s and began to challenge the then existing international financial order, the estimation results by including Japan in the sample has an important implication for other potential major currency countries such as China.

\section{Implications for RMB Internationalization}

Now, what do all these empirical findings suggest for the actively debated issue of RMB internationalization? 
Indeed, the initiative to 'internationalize' the RMB started with an effort to promote the use of the RMB for trade-related purposes. In July 2009, China launched a pilot scheme that allowed the use of the RMB in trade settlement with the Association of Southeast Asian Nations (ASEAN) member states as well as Hong Kong and Macau in five mainland cities: Shanghai, Guangzhou, Shenzhen, Dongguan, and Zhuhai. In mid-2010, coverage of the scheme was expanded to 20 provinces, permitting firms in those provinces to settle their trade in RMB. Since then, authorization to settle trade in RMB has been extended nationwide, so that essentially all trade by China is now allowed to be settled in RMB.

Growth has been rapid. From a mere $0.02 \%$ of China's total trade in 2009 , the first year of the pilot scheme, RMB trade settlement had ballooned to $32.7 \%$ of China's total trade by the third quarter of 2015 while it declined to $26 \%$ in the first quarter of $2016 .{ }^{37}$ Since the inception of the scheme, more than $80 \%$ of these trade settlements have been with Hong Kong, however, raising some questions about the generality of RMB use in trade settlement for China.

Initially, RMB trade settlement was skewed toward import settlement rather than export settlement. For example, at the end of 2010 the ratio of RMB receipts and payments was 1:5.5 (People's Bank of China 2012). One interpretation of this bias is that it likely reflected the lack of availability of RMB abroad and the incentive to continue to hold RMB offshore in anticipation of the currency's appreciation. In other words, it may have reflected speculative motives rather than the convenience of settling trade in the RMB.

More recently, the ratio has narrowed, falling to $1: 1.40$ in 2014 , and reversed to 1:0.96 in 2015 (People's Bank of China 2014, 2015). This trend is in line with the turnaround in expectations of a RMB appreciation since the latter part of 2011. Indeed the utilization of RMB in trade settlement has declined since the fourth quarter of 2015 when expectations of RMB depreciation were widely held in the markets. Nonetheless, RMB internationalization is likely to be driven by fundamental changes once the financial and currency markets are stabilized.

The use of RMB as a settlement currency has risen over the last six years, but it is not as high as what China's trade share in the world suggests. Figure 4 plots the share of export invoiced in each of the sample currency against the country's share of export in world export (with both shares averaged over 2009-13). The figure clearly demonstrates that the RMB is still

\footnotetext{
${ }^{37}$ China publishes data only on RMB settlements, not invoicing. Yu (2012) argues that a large bulk of the imports settled in RMB is often initially invoiced in U.S. dollar. He discusses the implications of the discrepancy between the levels of trade invoicing and settlements for China.
} 
underutilized; although China's share of export in world export is about 10\%, the RMB's share in export invoicing (settlement in the case of China) is minimal, appearing as an outlier. Excluding China, there is a moderate positive correlation between the share of export invoiced in a country's home currency and the share of the country's export in the world's total export. Although the other two large exporters, Germany and Japan, also appear to be off the fitted line, China's deviation appears more substantial, indicating substantial room for greater RMB use for trade invoicing.

In Figure 5, the RMB shares in export and import invoicing are compared with those of the yen and the DM (or the euro after its introduction in 1999) shares. Interestingly, we observe that the RMB settlement share for China's import has caught up with the yen invoicing share for Japan's import. ${ }^{38}$ The RMB share for export settlement is still lower by some twenty percentage points than the yen share for Japan's export invoicing, but the RMB appears to be rapidly catching up with the yen. However, it is unclear whether the RMB use for trade settlement will become as prevalent as the DM use was or the euro use is at present.

Our regression analysis in the previous section has found some results that are useful in assessing the future course of RMB internationalization. First, a country with a rising trade share in the global economy tends to use its currency for trade invoicing. Second a country with a rising level of per capital income tends to use its currency for trade invoicing. Third, although a country's financial market development itself may not raise its currency use for trade invoicing, its financial market development combined with greater market openness tends to lead to greater use of the country's currency for trade invoicing. Fourth, a country that trades with U.S. dollarzone partners tend to invoice its trade less in its own currency.

These findings indicate that the current high level of China's share in global trade and its continued growth of per capita income will be positive factors for rising use of the RMB as a trade invoicing currency.

In fact, these two issues had significant impacts on the yen. In Table 9, we saw that any major currency country, except the U.S., tends to invoice its export or import more in its home currency when it is a larger exporter or importer in world trade. This tendency is also stronger when its per capita income is higher. However, in the case of Japan, its global presence both as a

\footnotetext{
38 The RMB is unique in the sense that the share in import invoicing is higher than that in export invoicing, unlike stylized facts among most of the currencies that the share is higher for exports than for imports (Grassman's Law, 1973).
} 
major trading country and as a high per-capita-income country peaked in the early 1990s and has since declined over time as a trend. The positive effects of these factors also suggest that the declines in the trade share and per capita income may have been the main reason for the stagnant use of the yen in international markets after the 1990s.

Given these observations, we examine what would have happened to the share of the yen in trade invoicing if Japan's global presence as a large trading nation and as a high income country (relative to the U.S.) had continued to stay at their respective peak levels, that is, if the share of Japan's exports (imports) in world trade had stayed at 10.3\% (7.4\%) from 1986 (1980) onward and if its relative per capita income level stayed at $85.5 \%$ from 1995 onward.

Figure 6 illustrates the predicted shares of the yen in export and import invoicing under the assumption that Japan's export and import shares in world trade as well as its per capita income had been at the peak levels in the years after their respective peaks were achieved. ${ }^{39}$ Interestingly, in this hypothetical case, the share of the yen in Japan's export invoicing would have been as high as $75 \%$ by the 2010 s, while the share of yen import invoicing would have been more than $35 \%$.

This analysis shows that the diminishing presence of Japan in the world economy, in terms of its international trade volume and its per capita income level, contributed to the lack of further progress in the international use of the yen after the 1990s. Considering that the Chinese economy started to show some sign of growth slowdown in 2015-16, these results suggest that the slowdown of Chinese economic growth may negatively contribute to RMB internationalization.

A more crucial issue for China in further promoting the RMB's use for trade invoicing is that the country needs to further develop and open its financial market through market reforms and capital account liberalization. Chinese authorities, however, continue to intervene in the allocation of bank credit for state-owned commercial banks and the stock market tends to be dominated by households rather than institutional investors. Following the stock market crash in the summer of 2015, RMB devaluations in August that year, and massive capital outflows, it is unclear how far Chinese authorities are willing to lift capital controls to further open the financial market and make the RMB exchange rate truly market determined. Our results signify

39 The dashed line in each panel indicates the peak year for Japan's export or import share. 
the importance of not just financial market development but also financial market openness. In this context, the prospect of further RMB internationalization is uncertain.

In addition, the presence of the U.S. dollar bloc in Asia stands as a major challenge to the greater use of the RMB for trade invoicing, because China's main trading partners are U.S. dollar-zone countries, particularly in Asia (Aizenman and Ito, 2016). Furthermore, as the prospect of the world economy gets gloomy due to the slowdown of emerging market economies, the demand for holding on to the dollar as a safe haven currency can contribute to making it harder for the RMB to challenge the dollar-centric international monetary system.

\section{Concluding Remarks}

We have examined the experiences of major currencies, such as the U.S. dollar, Japanese yen, and Deutsche mark, used for trade invoicing in the 1970s through the 1990s. What we have found is that the U.S. dollar was (and still is) unequivocally the global trade-invoicing currency used extensively by economies around the world, that the DM was the most important regional invoicing currency used by European countries, and that the yen was (and still is) neither a global nor a regional currency. The yen's use for trade invoicing was low even for Japan itself despite its being one of the world's largest exporters.

We have conducted panel regression analysis to examine the determinants of the shares of major currencies, including the U.S. dollar, yen, DM, U.K. pound, French franc, Italian lira, and Swiss franc, which were used for trade invoicing by third economies, i.e., economies other than the major currency countries. The estimation results have confirmed several interesting points. First, the share of a major currency used for trade invoicing was positively affected by these economies' export shares with the major-currency country, but this did not apply to the dollar, that is, the use of the dollar was not driven merely by trade ties with the U.S. Second, the share of major currency invoicing was negatively affected by financial market development and openness in non-major currency economies, which suggests that an economy with a more developed and a more open financial market tended to invoice its exports in its own (home) currency. Third, an economy with a high commodity trade ratio tended to invoice its exports predominantly in the U.S. dollar. Countries with macroeconomic instability tended to invoice trade in the DM, implying that these countries regarded the DM as an anchor currency. 
We have conducted another panel regression analysis by using alternative measures of exchange rate regimes for non-major currency economies. To do so, we have obtained major currency weights in the implicit currency baskets of these economies and also constructed the shares of trade with the major currency zones for each of these economies. We find that both the major-currency weights and trade shares with different currency zones affected the major currency share used for trade invoicing. The U.S. dollar and the DM were found to be in a rivalry relationship. That is, an economy attempting to stabilize its exchange rate against the U.S. dollar tended to invoice its exports more in the U.S. dollar and less in the DM, while an economy stabilizing its exchange rate against the DM tended to invoice more in the DM and less in the dollar. In addition, an economy that traded heavily with dollar-zone countries tended to invoice its exports more in the dollar and less in the DM, while the opposite held for an economy trading heavily with DM-zone countries. The yen was not in such a rivalry relationship with either the U.S. dollar or the DM.

The yen and the DM differed from each other in terms of the spread of their currency zones. European countries belonged primarily to the DM zone, which led to high DM shares for trade invoicing among these countries, while Asia-Oceania countries belonged, and still belongs, predominantly to the U.S. dollar zone, leading to a lower use of the yen for trade invoicing. The high degree of DM use by European countries led to a smooth transition to the Euro Area, while the degree of yen use was limited even by Japan.

We have also examined how conditions in the major currency countries affected the use of their own currencies - while excluding U.S. dollar observations. We find that major currency countries tended to invoice their trade in their own currencies when they had a large presence in international trade (in terms of the share in world trade) and had higher levels of per capita income. The level of per capita income tended to be highly correlated with the level of differentiation in goods and services a country produces and, thus, the country's bargaining power to invoice trade in its home currency.

The estimation results show that a major currency country with a more developed financial market tended to invoice its trade less in its own currency, while a major currency country with a more open financial market tended to invoice its exports more in its own currency. The puzzling negative impact of financial development on own currency invoicing was mitigated when the country had a developed and sufficiently open financial market. Furthermore, 
a major currency country with high shares of trade with U.S. dollar zone countries tended to invoice its trade less in its own currency.

We have then suggested several implications for China's RMB internationalization. China's presence as a large trading nation and its continued rise in its per capita income will contribute to greater use of the RMB for trade invoicing. Its continuous efforts at liberalizing and opening its financial market will be critical for further use of the RMB as an invoicing currency. However, a high share of its trade with U.S. dollar zone economies, particularly in Asia, is likely to be a big hurdle for China to increase its use of RMB for its own trade invoicing. 


\section{Data Appendix:}

Share of export/import - The share of country $i$ 's export to, or import from, a major currency country (e.g., Japan) in country $i$ 's total export or import. The data are taken from the IMF's Direction of Trade.

Commodity export/import as a percentage of total export/import - Data are taken from the World Bank's World Development Indicators and the IMF's International Financial Statistics.

Relative income to the U.S. - The relative per capita income level to the U.S. as a proxy. Data for the real per capita income (in PPP) are taken from Penn World Table 8.0.

Exchange rate volatility and inflation rate differential - Exchange rate volatility for country $i$ is calculated as annual standard deviations of the monthly rates of change in the exchange rate (data taken from the International Financial Statistics, IFS) against the currency of the major currency of concern. The inflation rate differential for country $i$ is calculated as the difference in the annual rates of CPI inflation (data taken from IMF's International Financial Statistics) between country $i$ and the major-currency country.

European Union membership - The countries included in the EU are: Austria, Belgium, Bulgaria, Cyprus, Czech Republic, Denmark, Estonia, Finland, France, Germany, Greece, Hungary, Ireland, Italy, Latvia, Lithuania, Luxembourg, Malta, Netherlands, Poland, Portugal, Romania, Slovak Republic, Slovenia, Spain, Sweden, and the United Kingdom. The dummy for the EU membership is assigned for the entire sample period regardless of the year of entry to the union, i.e., time-invariant.

Financial development/size - Financial development/size $(F D)$ is defined as the product of private credit creation as a share of GDP and the relative size of private credit creation in country $i$ to the world's total private credit creation. Data are taken from the World Bank's Financial Structure Database (first introduced by Beck, et al., 2001).

Financial openness - Data are the Chinn-Ito index of capital account openness (Chinn and Ito, 2006, 2008, and updates). The index is based on information regarding regulatory restrictions on cross-border capital transactions reported in the IMF's Annual Report on Exchange Arrangements and Exchange Restrictions (AREAER). Specifically, it is the first standardized principal component of the variables that indicate the presence of multiple exchange rates, restrictions on current account transactions, restrictions on capital account transactions, and the requirement of the surrender of export proceeds (see Chinn and Ito, 2006 and 2008). The index is normalized to range between zero and one. High values indicate more open capital account. The original index is available at http://web.pdx.edu/ ito/Chinn-Ito_website.htm .

Dummies for a U.S.-dollar peg or a DM peg - Data are constructed based on the information in the IMF's Annual Report on Exchange Arrangements and Exchange Restrictions (AREAER).

Dummies for former U.K. or French colonies - Data are obtained from the CIA Factbook

Currency weights - Estimated as explained in the text with moving 36-month rolling regressions, using monthly data from the IMF's International Financial Statistics. Outliers observed for the estimated $\hat{\beta}_{i h t}$ due to financial or macroeconomic turbulences are deleted on a monthly basis. Any significantly negative $\hat{\beta}_{i h t}$ is assumed to be a missing estimate and a statistically 
insignificant negative $\hat{\beta}_{i h t}$ is replaced with a value of zero. Likewise, any $\hat{\beta}_{i h t}$ that is significantly no greater from the value of one is replaced with the value of one, while $\hat{\beta}_{i h t}$ significantly greater than one is replaced with a missing variable. Once outliers are removed and some estimates are replaced with other valued on a monthly basis, they are annually averaged to create annual data series.

Currency zone trade share - See the text. 


\section{References}

Aizenman, Joshua and Hiro Ito. 2016. "East Asian Economies and Financial Globalization In the Post-Crisis World,” NBER Working Paper \#22268 (May 2016).

Auboin, Marc. 2012. "Use of Currencies in International Trade: Any Changes in the Picture?" WTO Staff Working Paper ERSD-2012-10. Geneva: World Trade Organization Economic Research and Statistics Division (May).

Bacchetta, Philippe and Eric Van Wincoop. 2005. "A Theory of the Currency Denomination of International Trade.” Journal of International Economics 67(2): 295-319.

Bank of International Settlements. 2013. Triennial Central Bank Survey on Foreign Exchange Turnover in April 2013: Preliminary Global Results, Basel, available at www.bis.org

Bank of International Settlements. 2010. Triennial Central Bank Survey on Foreign Exchange, Basel, available at www.bis.org

Beck, Thorsten, Asli Demirgüc-Kunt, and Ross Levine. 2001. "A new database on financial development and structure.” Policy Research Paper No. 2147 (Washington, D.C.: World Bank).

Bénassy-Quéré, A., B. Coeuré, and V. Mignon. 2006. "On the Identification of De Facto Currency Pegs." Journal of the Japanese and International Economies, vol 20, pp 11227.

Chinn, M.D. and H. Ito. 2006. "What Matters for Financial Development? Capital Controls, Institutions, and Interactions." Journal of Development Economics 81 (1), 163-192.

Chinn, M.D. and H. Ito. 2007. "Current Account Balances, Financial Development and Institutions: Assaying the World 'Savings Glut'." Journal of International Money and Finance, Volume 26, Issue 4, p. 546-569 (June 2007),

Chinn, M.D. and H. Ito. 2008. “A New Measure of Financial Openness.” Journal of Comparative Policy Analysis, Volume 10, Issue 3 (September): 309-22.

Da Silva, Jorge. 2004. "Determinants of the Choice of Invoicing Currency: From Dutch Guilders to Euros in Dutch Goods Trade." Tilburg University. Mimeo.

Donnefeld, Shabtai and Alfred Huag. 2003. "Currency Invoicing in International Trade: an Empirical Investigation." Review of International Economics 11: 332-345.

Donnefeld, S. and I. Zilcha. 1991. "Pricing of Exports and Exchange Rate Uncertainty." International Economic Review 32 (4): 1009-1022.

Dornbusch, R. 1987. "Exchange Rates and Prices." American Economic Review, 77, pp. 93-106. Eichengreen, B. 2011. Exorbitant Privilege: The Rise and Fall of the Dollar and the Future of the International Monetary System. Oxford University Press, January 2011.

Eichengreen, Barry and Masahiro Kawai. 2015. "Introduction and Overview." In B. Eichengreen and M. Kawai, eds., Renminbi Internationalization: Achievements, Prospects, and Challenges, Washington, DC: Brookings Institution Press, pp. 1-23.

European Central Bank. 2013, 2012, 2011, 2010, 2009, 2008. "International Role of the Euro." Frankfurt: European Central Bank (July).

European Central Bank. 2007. "Review of the International Role of the Euro." Frankfurt: European Central Bank (June).

European Central Bank. 2005. "Review of the International Role of the Euro.” Frankfurt: European Central Bank (January).

Frankel, J. 2011. "Historical Precedents for Internationalization of the RMB." A CGS/IIGG Working Paper. Washington, D.C.: Council on Foreign Relations. 
Frankel, J. and S. J. Wei. 1996. "Yen Bloc or Dollar Bloc? Exchange Rate Policies in East Asian Economies.” In T. Ito and A Krueger, eds., Macroeconomic Linkage: Savings, Exchange Rates, and Capital Flows, Chicago: University of Chicago Press, pp 295-329.

Fukuda, Shin-ichi and Ji Cong. 1994. "On the Choice of Invoice Currency by Japanese Exporters: The PTM Approach.” Journal of the Japanese and International Economies, 8, pp 511-529.

Goldberg, Linda and Cédric Tille. 2005. "Vehicle Currency Use in International Trade." NBER Working Paper No. 11127. Cambridge: National Bureau of Economic Research.

Goldberg, Linda and Cédric Tille. 2008. "Vehicle Currency Use in International Trade.” Journal of International Economics, 76(2) (January), pp. 177-192.

Goldberg, Linda and Cédric Tille. 2009. "Macroeconomic Inter-dependence and the International Role of the Dollar." Journal of Monetary Economics Volume 56:7 (October), 21.

Goldberg, Linda and Cédric Tille. 2010. "What Drives the Invoicing of International Trade." Voxeu.org column.

Gopinath, Gita. 2015. “The International Price System.” NBER Working Paper No. 21646 (October). Cambridge: National Bureau of Economic Research.

Gopinath, G., Itskhoki, O., and Rigobon, R. 2010. "Currency Choice and Exchange Rate PassThrough.” American Economic Review, 100(1), pp. 304-36.

Grassman, S. 1973. "A Fundamental Symmetry in International Payments Patterns. ” Journal of International Economics, May, 3(2), pp. 105-16.

Haldane, A. and S. Hall. 1991. "Sterling's Relationship with the Dollar and the Deutschemark: 1976-89.” Economic Journal, 101:406 (May).

Ito, H. and M. Chinn. 2015. "The Rise of the 'Redback' and China's Capital Account Liberalization: An Empirical Analysis on the Determinants of Invoicing Currencies." In Eichengreen, B. and M. Kawai, eds., Renminbi Internationalization: Achievements, Prospects, and Challenges (January 2015).

Ito, H. and C. Rodriguez. 2015. "Clamoring for Greenbacks: Explaining the Resurgence of the US Dollar in International Debt.” RIETI Working Paper 15-E-119 (October).

Ito, H., R. McCauley, T. Chan. 2015. "Emerging Market Currency Composition of Reserves, Denomination of Trade and Currency Movements." Forthcoming in Emerging Markets Review (October 2015).

Ito, Takatoshi. 2011. "The Internationalization of the RMB: Opportunities and Pitfalls." CGS/IIGG Working Paper. Washington, D.C.: Council on Foreign Relations.

Ito, Takatoshi, Satoshi Koibuchi, Kiyotaka Sato, and Junko Shimizu. 2010. "Why the Yen Failed to Become a Dominant Invoicing Currency in Asia? A Firm-Level Analysis of Japanese Exporters’ Invoicing Behavior.” NBER Working Paper No. 16231. Cambridge: National Bureau of Economic Research.

Ito, T., Koibuchi, S., Sato, K., and Shimizu, J. 2012. "The Choice of an Invoicing Currency by Globally Operating Firms: A Firm-Level Analysis of Japanese Exporters." International Journal of Finance \& Economics, 17(4), pp. 305-320.

Kamps, A. 2006. "The Euro as Invoicing Currency in International Trade.” European Central Bank Working Paper Series No. 665 (August). Frankfurt: European Central Bank.

Kawai, Masahiro. 1996. "The Japanese Yen as an International Currency: Performance and Prospects.” In Ryuzo Sato, Rama V. Ramachandran, and Hajime Hori, eds., 
Organization, Performance and Equity: Perspectives on the Japanese Economy, Boston, London, Dordrecht: Kluwer Academic Publishers, pp. 305-355.

Kawai, M. and S. Akiyama. 1998. "The role of Nominal Anchor Currencies in Exchange Rate Arrangements." Journal of the Japanese and International Economies, 12, pp 334-87.

Kawai, M. and V. Pontines. 2016. "Is There Really a Renminbi Bloc in Asia?: A Modified Frankel-Wei Approach.” Journal of International Money and Finance, 62 (April), pp. 72-97.

Kenen, P. 1983. "The Role of the Dollar as an International Reserve Currency." Occasional Papers No. 13, Group of Thirty.

Kose, M. A., E. Prasad, K. Rogoff, and S. J. Wei. 2006. "Financial Globalization: A Reappraisal.” IMF Working Paper, WP/06/189. Washington, D.C.: International Monetary Fund.

Krugman, P. 1987. "Pricing to Market when the Exchange Rate Changes." In S. W. Arndt and J. D. Richardson, eds., Real Financial Linkages among Open Economies. Cambridge, Mass.: MIT Press.

Ligthart, Jenny E. and Sebastian E. V. Werner. 2012. "Has the Euro Affected the Choice of Invoicing Currency?” European Central Bank Working Paper Series No. 1414 (January). Frankfurt: European Central Bank.

McKinnon, R. 1979. Money in international exchange. New York: Oxford University Press.

Maziad, Samar, Pascal Farahmand, Shengzu Wang, Stephanie Segal, and Faisal Ahmed. 2011. "Internationalization of Emerging Market Currencies: A Balance between Risks and Rewards.” IMF Staff Discussion Note SDN/11/17 (October). Washington, D.C.: International Monetary Fund.

Oi, H., A. Otani, and T. Shirota. 2004. "The Choice of Invoice Currency in International Trade: Implications for the Internationalization of the Yen." Monetary and Economic Studies 22 (1), pp. 27-63.

Page, S. A. B. 1977. "The Currency of Invoicing in Merchandise Trade." National Institute Economic Review, 81, pp. 77-8 1.

Page, S. A. B. 1981. "The Choice of Invoicing Currency in Merchandise Trade." National Institute Economic Review, 98, pp. 60-72.

People's Bank of China. 2015, 2014, 2013, 2012, 2011, 2010. Annual Report. Beijing: People's Bank of China.

Prasad, E. and L. Ye. 2012. “The Reminbi’s Role in the Global Monetary System.” IZA Discussion Papers 6335, Institute for the Study of Labor (IZA).

Rauch, James E. 1999. "Networks Versus Markets in International Trade." Journal of International Economics 48(1) (June), pp. 7-35.

Sasaki, Y. N. 2002. "Pricing-to-Market Behavior: Japanese Exports to the US, Asia, and the EU." Review of International Economics 10 (1), pp. 140-150.

Subramanian, A., Kessler, M. 2012. "The Renminbi Bloc Is Here: Asia Down, Rest of the World to Go?" Peterson Institute for International Economics Working Paper WP 12-19 (October). Washington, DC: Peterson Institute for International Economics.

Takagi, Shinji. 2009. "Internationalizing the Yen, 1984-2000: Unfinished Agenda or Mission Impossible." A paper presented at the BoK-BIS Seminar on Currency Internationalization: Lessons from the Global Financial Crisis and Prospects for the Future in Asia and the Pacific. 
Tavlas, George S. 1991. "On the International Use of Currencies: The Case of the Deutsche Mark." Essays in International Finance, 181. Princeton: Princeton University.

Tavlas, George S. and Yuzuru Ozeki. 1992. "The Internationalization of Currencies: An Appraisal of the Japanese Yen.” IMF Occasional Paper 90 (January). Washington, D.C.: International Monetary Fund.

Willander, Fredrick. 2006. "An Empirical Analysis of the Currency Denomination in International Trade." Mimeo. Stockholm: Stockholm School of Economics.

Yu, Yongding. 2013. "How Far Internationalization of the RMB Can Go?” Mimeo. Beijing: Chinese Academy of Social Sciences.

Yu, Yongding. 2012. "Revisiting the Internationalization of the Yuan.” ADBI Working Paper, 366 (July). Tokyo: Asian Development Bank Institute. 
Table 1: Shares of Home and Major Currencies for Export Invoicing in Europe and Asia-Oceania

(a) European countries

\begin{tabular}{|c|c|c|c|c|c|c|}
\hline Germany & 1972 & 1979 & 1987 & 1995 & 2005 & 2012 \\
\hline Home & 84.1 & 82.6 & 81.5 & 74.7 & 61.0 & 64.6 \\
\hline USD & 6.5 & 7.2 & 7.4 & & & 25.6 \\
\hline DM/EURO & 84.1 & 82.6 & 81.5 & 74.7 & 61.0 & 64.6 \\
\hline YEN & & 0.0 & 0.5 & 0.9 & & \\
\hline Belgium & 1972 & 1979 & 1987 & 1995 & 2005 & 2012 \\
\hline Home & 46.0 & 44.2 & & & 54.8 & 56.6 \\
\hline USD & 11.9 & 12.5 & & & & \\
\hline $\begin{array}{l}\text { DM/EURO } \\
\text { YEN }\end{array}$ & 18.1 & 17.9 & & & 54.8 & 56.6 \\
\hline Denmark & 1972 & 1979 & 1987 & 1995 & 2005 & 2012 \\
\hline Home & 47.0 & 51.0 & & & & 18.3 \\
\hline USD & 16.0 & 16.0 & & & & 33.7 \\
\hline DM/EURO & 8.0 & 12.0 & & & & 22.3 \\
\hline YEN & & & & & & \\
\hline France & 1972 & 1979 & 1987 & 1995 & 2005 & 2012 \\
\hline Home & 59.4 & 62.4 & 62.4 & 51.7 & 49.8 & 48.4 \\
\hline USD & 10.3 & 11.6 & 14.8 & 18.6 & 37.4 & 38.5 \\
\hline DM/EURO & 10.6 & 10.2 & 9.5 & 10.5 & 49.8 & 48.4 \\
\hline YEN & & & & 1.0 & & \\
\hline Italy & 1972 & 1979 & 1987 & 1995 & 2005 & 2012 \\
\hline Home & 50.7 & 36.0 & 38.0 & 40.0 & 58.3 & 72.6 \\
\hline USD & 28.3 & 30.0 & 20.0 & 21.0 & & 24.3 \\
\hline DM/EURO & & & 18.0 & 18.0 & 58.3 & 72.6 \\
\hline YEN & & 0.1 & 0.4 & 0.6 & & \\
\hline Netherlands & 1972 & 1979 & 1987 & 1995 & 2005 & 2012 \\
\hline Home & 44.2 & 42.9 & 45.7 & 43.8 & & 56.4 \\
\hline USD & 13.2 & 19 & 16.9 & 20.6 & & 37.6 \\
\hline DM/EURO & 20.4 & & 18.6 & 18.5 & & 56.4 \\
\hline YEN & & & 0.3 & 0.6 & & \\
\hline U.K. & 1972 & 1979 & 1987 & 1995 & 2005 & 2012 \\
\hline Home & & 76.0 & 57 & 61.6 & & 51.1 \\
\hline USD & & 17.0 & 26 & 23.1 & & 28.8 \\
\hline DM/EURO & & 3.0 & 4.0 & 4.0 & & 3.1 \\
\hline YEN & & & 0.5 & 1.1 & & 0.4 \\
\hline
\end{tabular}

(b) Asia-Oceania countries

\begin{tabular}{|c|c|c|c|c|c|c|}
\hline Japan & 1972 & 1979 & 1987 & 1995 & 2005 & 2012 \\
\hline Home & 8.7 & 24.8 & 33.4 & 37.6 & 38.85 & 39.4 \\
\hline USD & 82.8 & 70.7 & 55.2 & 51.5 & 49.15 & 50.35 \\
\hline DM/EURO & 1.3 & 1.6 & 3.0 & 2.4 & 8.35 & 5.45 \\
\hline YEN & 8.7 & 24.8 & 33.4 & 37.6 & 38.85 & 39.4 \\
\hline Australia & 1972 & 1979 & 1987 & 1995 & 2005 & 2012 \\
\hline Home & & & & & 23.5 & 13.7 \\
\hline USD & & 70.0 & & & 72.6 & 84 \\
\hline DM/EURO & & 1.0 & & & 1.1 & 1 \\
\hline YEN & & & & & 0.7 & 0.3 \\
\hline New Zealand & 1972 & 1979 & 1987 & 1995 & 2005 & 2012 \\
\hline Home & & & & & 26.5 & 22.0 \\
\hline USD & & & & & 48.9 & 59.0 \\
\hline DM/EURO & & & & & 7.8 & 5.4 \\
\hline YEN & & & & & 2.7 & 1.9 \\
\hline India & 1972 & 1979 & 1987 & 1995 & 2005 & 2012 \\
\hline Home & & & & 1.8 & 1.9 & \\
\hline USD & & & & 80.9 & 85.8 & 88.41 \\
\hline DM/EURO & & & & 5.4 & 7.6 & 7.0 \\
\hline YEN & & & & 0.5 & 0.5 & 0.15 \\
\hline Indonesia & 1972 & 1979 & 1987 & 1995 & 2005 & 2012 \\
\hline Home & & & & 0.0 & 0.6 & 0.8 \\
\hline USD & & & & 94.3 & 91.3 & 93.3 \\
\hline DM/EURO & & & & 0.5 & 1.8 & 1.3 \\
\hline YEN & & & & 1.5 & 2.1 & 1.4 \\
\hline Korea & 1972 & 1979 & 1987 & 1995 & 2005 & 2012 \\
\hline Home & & & & 0.1 & 0.5 & 2.2 \\
\hline USD & & 98.8 & 91.7 & 88.0 & 82.9 & 85.1 \\
\hline DM/EURO & & 0.7 & 1.2 & 2.4 & 8.5 & 5.5 \\
\hline YEN & & 0.2 & 5.7 & 7.3 & 5.6 & 4.3 \\
\hline Thailand & 1972 & 1979 & 1987 & 1995 & 2005 & 2012 \\
\hline Home & & & & 2.4 & 6.8 & 10.0 \\
\hline USD & & & & 91.0 & 81.7 & 79.7 \\
\hline DM/EURO & & & & 0.5 & 2.6 & 2.2 \\
\hline YEN & & & & 4.1 & 6.4 & 5.9 \\
\hline
\end{tabular}


Table 2-1: Determinants of the Shares of Japanese Yen, Deutsche Mark, and the U.S. Dollar in Export Invoicing of Non-Major Currency Economies, 1970-1998

\begin{tabular}{|c|c|c|c|c|c|c|c|c|c|}
\hline & \multicolumn{3}{|c|}{ JAPANESE YEN } & \multicolumn{3}{|c|}{ GERMAN DEUTSCHE MARK } & \multicolumn{3}{|c|}{ U.S. DOLLAR } \\
\hline & $\begin{array}{l}\text { Random } \\
\text { Effects } \\
\text { (1) } \\
\end{array}$ & $\begin{array}{c}\text { Fixed } \\
\text { Effects } \\
(2)\end{array}$ & $\begin{array}{c}\text { PCSE } \\
\text { w/ weights } \\
\text { (3) }\end{array}$ & $\begin{array}{l}\text { Random } \\
\text { Effects } \\
(4)\end{array}$ & $\begin{array}{c}\text { Fixed } \\
\text { Effects } \\
(5)\end{array}$ & $\begin{array}{c}\text { PCSE } \\
\text { w/ weights } \\
\text { (6) }\end{array}$ & $\begin{array}{l}\text { Random } \\
\text { Effects } \\
(7)\end{array}$ & $\begin{array}{l}\text { Fixed } \\
\text { Effects } \\
(8)\end{array}$ & $\begin{array}{c}\text { PCSE } \\
\text { w/ weights } \\
\text { (9) }\end{array}$ \\
\hline Share of export & $\begin{array}{c}0.112 * * \\
(0.047)\end{array}$ & $\begin{array}{c}0.163 * * * \\
(0.053)\end{array}$ & $\begin{array}{l}-0.027 \\
(0.039)\end{array}$ & $\begin{array}{c}0.511 * * * \\
(0.056)\end{array}$ & $\begin{array}{c}0.461 * * * \\
(0.061)\end{array}$ & $\begin{array}{c}0.912 * * * \\
(0.060)\end{array}$ & $\begin{array}{c}0.123 \\
(0.110)\end{array}$ & $\begin{array}{c}-0.438 * * * \\
(0.128)\end{array}$ & $\begin{array}{c}0.313 \\
(0.256)\end{array}$ \\
\hline Commodity export (\%) & $\begin{array}{l}-0.039 \\
(0.030)\end{array}$ & $\begin{array}{c}-0.078^{*} \\
(0.045)\end{array}$ & $\begin{array}{c}-0.036 * * * \\
(0.012)\end{array}$ & $\begin{array}{c}-0.047 * \\
(0.028)\end{array}$ & $\begin{array}{l}-0.060 \\
(0.036)\end{array}$ & $\begin{array}{c}-0.100 * * * \\
(0.022)\end{array}$ & $\begin{array}{c}0.243 * * * \\
(0.089)\end{array}$ & $\begin{array}{c}0.040 \\
(0.156)\end{array}$ & $\begin{array}{c}0.169 * * \\
(0.079)\end{array}$ \\
\hline Relative income to U.S. & $\begin{array}{c}0.071 * * * \\
(0.019)\end{array}$ & $\begin{array}{c}0.121 * * * \\
(0.026)\end{array}$ & $\begin{array}{c}0.033 * * * \\
(0.005)\end{array}$ & $\begin{array}{c}0.017 \\
(0.014)\end{array}$ & $\begin{array}{c}0.022 \\
(0.015)\end{array}$ & $\begin{array}{l}-0.015 \\
(0.011)\end{array}$ & $\begin{array}{c}-0.356 * * * \\
(0.055)\end{array}$ & $\begin{array}{c}-0.508 * * * \\
(0.074)\end{array}$ & $\begin{array}{c}-0.355^{* * *} \\
(0.068)\end{array}$ \\
\hline Exchange rate volatility & $\begin{array}{l}-0.000 \\
(0.004)\end{array}$ & $\begin{array}{l}-0.001 \\
(0.004)\end{array}$ & $\begin{array}{c}0.000 \\
(0.003)\end{array}$ & $\begin{array}{c}0.008 * * \\
(0.004)\end{array}$ & $\begin{array}{c}0.008 * * \\
(0.004)\end{array}$ & $\begin{array}{c}0.007 \\
(0.007)\end{array}$ & $\begin{array}{l}-0.005 \\
(0.019)\end{array}$ & $\begin{array}{l}-0.004 \\
(0.016)\end{array}$ & $\begin{array}{c}0.023 \\
(0.030)\end{array}$ \\
\hline Inflation rate differential & $\begin{array}{l}-0.033 \\
(0.026)\end{array}$ & $\begin{array}{c}-0.055^{*} \\
(0.031)\end{array}$ & $\begin{array}{c}-0.049 * * * \\
(0.012)\end{array}$ & $\begin{array}{l}-0.029 \\
(0.021)\end{array}$ & $\begin{array}{l}-0.026 \\
(0.021)\end{array}$ & $\begin{array}{c}0.099 * * \\
(0.042)\end{array}$ & $\begin{array}{c}0.068 \\
(0.093)\end{array}$ & $\begin{array}{c}0.222^{* *} \\
(0.105)\end{array}$ & $\begin{array}{c}0.173 \\
(0.208)\end{array}$ \\
\hline Financial development & $\begin{array}{c}-0.072 * * * \\
(0.014)\end{array}$ & $\begin{array}{c}-0.044 * * \\
(0.019)\end{array}$ & $\begin{array}{c}-0.041 * * * \\
(0.007)\end{array}$ & $\begin{array}{l}-0.024 \\
(0.023)\end{array}$ & $\begin{array}{l}-0.019 \\
(0.024)\end{array}$ & $\begin{array}{l}-0.014 \\
(0.020)\end{array}$ & $\begin{array}{c}-0.272 * * * \\
(0.065)\end{array}$ & $\begin{array}{c}-0.197 * * * \\
(0.065)\end{array}$ & $\begin{array}{c}-0.294 * * * \\
(0.092)\end{array}$ \\
\hline Financial openness & $\begin{array}{c}-0.021 * * \\
(0.008)\end{array}$ & $\begin{array}{l}-0.014 \\
(0.009)\end{array}$ & $\begin{array}{c}-0.012 * * \\
(0.006)\end{array}$ & $\begin{array}{c}0.007 \\
(0.006)\end{array}$ & $\begin{array}{c}0.009 \\
(0.006)\end{array}$ & $\begin{array}{l}-0.004 \\
(0.009)\end{array}$ & $\begin{array}{c}-0.105 * * * \\
(0.026)\end{array}$ & $\begin{array}{c}-0.091 * * * \\
(0.026)\end{array}$ & $\begin{array}{c}-0.119 * * * \\
(0.025)\end{array}$ \\
\hline Post-Bretton Woods & & & & $\begin{array}{c}0.004 \\
(0.003)\end{array}$ & $\begin{array}{c}0.003 \\
(0.003)\end{array}$ & $\begin{array}{c}0.004 * * \\
(0.002)\end{array}$ & $\begin{array}{c}0.000 \\
(0.017)\end{array}$ & $\begin{array}{l}-0.013 \\
(0.016)\end{array}$ & $\begin{array}{l}-0.010 \\
(0.027)\end{array}$ \\
\hline Pegged to U.S. dollar & $\begin{array}{c}-0.020 * * * \\
(0.004)\end{array}$ & $\begin{array}{c}-0.020 * * * \\
(0.004)\end{array}$ & $\begin{array}{c}-0.009 * * * \\
(0.003)\end{array}$ & $\begin{array}{l}-0.003 \\
(0.004)\end{array}$ & $\begin{array}{l}-0.002 \\
(0.004)\end{array}$ & $\begin{array}{l}-0.002 \\
(0.004)\end{array}$ & $\begin{array}{c}0.018 \\
(0.024)\end{array}$ & $\begin{array}{c}0.016 \\
(0.022)\end{array}$ & $\begin{array}{c}0.007 \\
(0.032)\end{array}$ \\
\hline Pegged to DM & $\begin{array}{l}-0.007 \\
(0.011)\end{array}$ & $\begin{array}{l}-0.005 \\
(0.011)\end{array}$ & $\begin{array}{l}-0.003 \\
(0.004)\end{array}$ & $\begin{array}{c}0.002 \\
(0.004)\end{array}$ & $\begin{array}{c}0.001 \\
(0.004)\end{array}$ & $\begin{array}{c}0.017 * * * \\
(0.006)\end{array}$ & $\begin{array}{c}0.073 * * * \\
(0.017)\end{array}$ & $\begin{array}{c}0.068 * * * \\
(0.016)\end{array}$ & $\begin{array}{c}0.060 * * * \\
(0.016)\end{array}$ \\
\hline EU membership & $\begin{array}{l}-0.029 \\
(0.025)\end{array}$ & & $\begin{array}{c}-0.041 * * * \\
(0.011)\end{array}$ & $\begin{array}{l}0.042^{*} \\
(0.022)\end{array}$ & & $\begin{array}{c}0.014 \\
(0.017)\end{array}$ & $\begin{array}{c}-0.368 * * * \\
(0.053)\end{array}$ & & $\begin{array}{c}-0.329 * * * \\
(0.057)\end{array}$ \\
\hline Former U.K. colony & $\begin{array}{l}-0.032 \\
(0.023)\end{array}$ & & $\begin{array}{c}-0.025 * * \\
(0.011)\end{array}$ & $\begin{array}{c}0.010 \\
(0.023)\end{array}$ & & $\begin{array}{c}0.045 * * * \\
(0.010)\end{array}$ & $\begin{array}{l}-0.025 \\
(0.056)\end{array}$ & & $\begin{array}{l}-0.022 \\
(0.036)\end{array}$ \\
\hline Former French colony & $\begin{array}{l}-0.009 \\
(0.027)\end{array}$ & & $\begin{array}{c}-0.027 * * \\
(0.013)\end{array}$ & & & & $\begin{array}{c}-0.406 * * * \\
(0.087)\end{array}$ & & $\begin{array}{c}-0.335^{* * * *} \\
(0.056)\end{array}$ \\
\hline East Asia \& Pacific & $\begin{array}{c}0.023 \\
(0.021)\end{array}$ & & $\begin{array}{c}0.013 \\
(0.011)\end{array}$ & $\begin{array}{c}0.003 \\
(0.023)\end{array}$ & & $\begin{array}{c}0.032 * * * \\
(0.007)\end{array}$ & $\begin{array}{c}0.127 * * \\
(0.052)\end{array}$ & & $\begin{array}{c}0.216 * * * \\
(0.062)\end{array}$ \\
\hline $\begin{array}{c} \\
\text { \# of economies }\end{array}$ & $\begin{array}{l}90 \\
17 \\
\end{array}$ & $\begin{array}{l}90 \\
17\end{array}$ & $\begin{array}{l}90 \\
17 \\
\end{array}$ & $\begin{array}{c}146 \\
19\end{array}$ & $\begin{array}{c}146 \\
19 \\
\end{array}$ & $\begin{array}{c}146 \\
19\end{array}$ & $\begin{array}{c}207 \\
29 \\
\end{array}$ & $\begin{array}{c}207 \\
29\end{array}$ & $\begin{array}{l}207 \\
29 \\
\end{array}$ \\
\hline $\begin{array}{c}\text { Overall R2 } \\
\text { W/in R2 } \\
\text { B/w R2 }\end{array}$ & $\begin{array}{l}0.65 \\
0.73 \\
0.33\end{array}$ & $\begin{array}{l}0.03 \\
0.74 \\
0.00\end{array}$ & . & $\begin{array}{l}0.87 \\
0.48 \\
0.83\end{array}$ & $\begin{array}{l}0.83 \\
0.48 \\
0.77\end{array}$ & . & $\begin{array}{l}0.93 \\
0.49 \\
0.85\end{array}$ & $\begin{array}{l}0.10 \\
0.56 \\
0.07\end{array}$ & . \\
\hline
\end{tabular}

Notes: $* p<0.1 ; * * p<0.05 ; * * * p<0.01$. The starting year for the yen share estimation is 1976 due to limited data availability. The estimate for the constant term is not reported. 
Table 2-2: Determinants of the Shares of UKP, FF, IL, and SF in Export Invoicing of Non-Major Currency Economies, 1970-1998

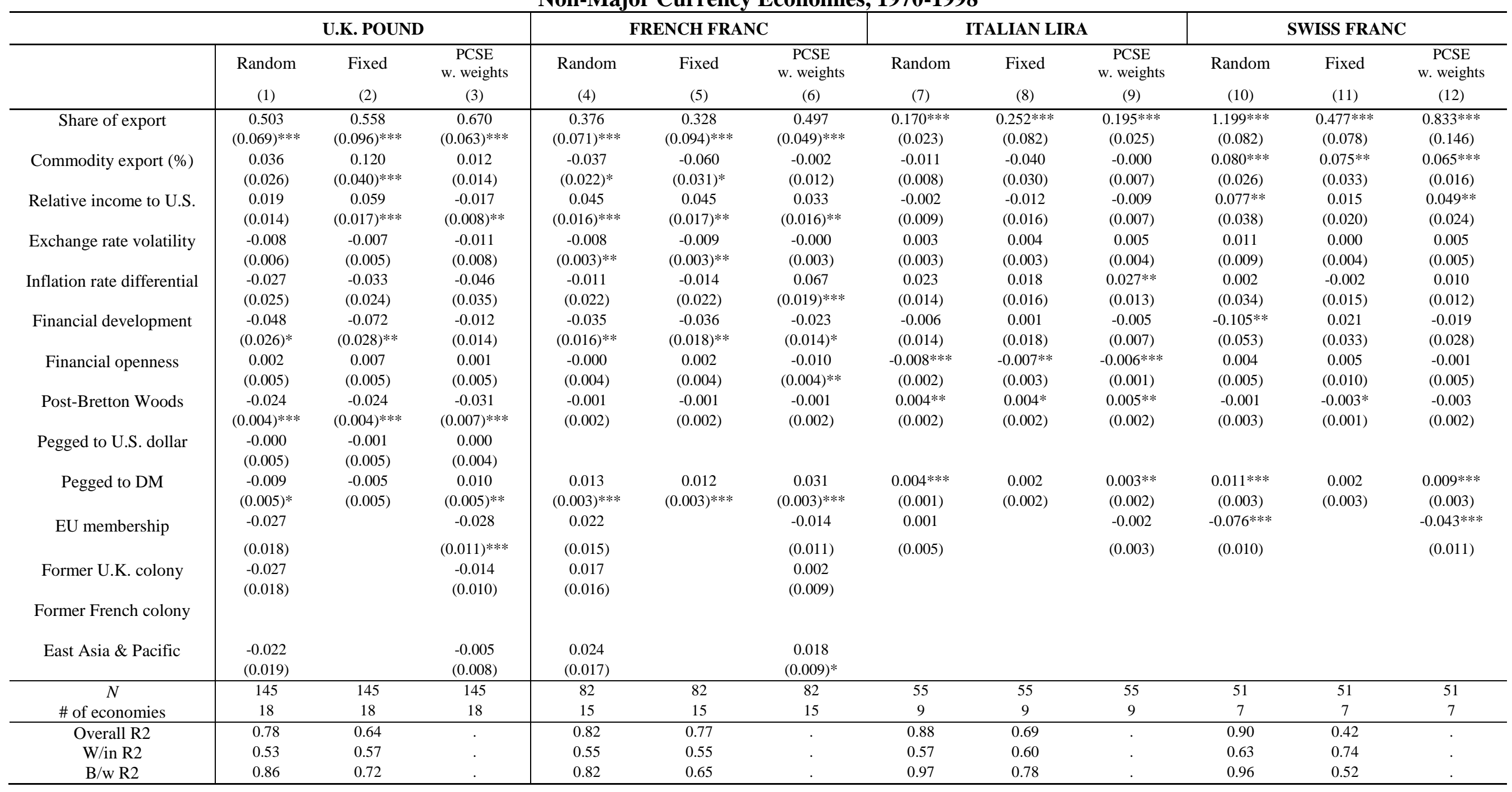

Note: $* p<0.1 ; * * p<0.05 ; * * * p<0.01$. The estimate for the constant term is omitted from presentation to conserve space. Due to data availability, the ending year for the estimations on the share of French franc is 1995. 
Table 3: Determinants of the Shares of the Japanese Yen, the DM, the U.S. Dollar in Import Invoicing of Non-Major Currency Economies, 1970-1998

\begin{tabular}{|c|c|c|c|c|c|c|c|c|c|}
\hline & \multicolumn{3}{|c|}{ JAPANESE YEN } & \multicolumn{3}{|c|}{ DEUTSCHE MARK } & \multicolumn{3}{|c|}{ U.S. DOLLAR } \\
\hline & $\begin{array}{c}\text { Random } \\
\text { (1) }\end{array}$ & $\begin{array}{l}\text { Fixed } \\
(2)\end{array}$ & $\begin{array}{c}\text { Random } \\
\text { (3) }\end{array}$ & $\begin{array}{c}\text { Random } \\
\text { (4) }\end{array}$ & $\begin{array}{l}\text { Fixed } \\
(5)\end{array}$ & $\begin{array}{c}\text { PCSE } \\
\text { w. weights } \\
(6)\end{array}$ & $\begin{array}{c}\text { Random } \\
\text { (7) }\end{array}$ & $\begin{array}{c}\text { Fixed } \\
(8)\end{array}$ & $\begin{array}{c}\text { PCSE } \\
\text { w. weights } \\
(9)\end{array}$ \\
\hline Share of import & $\begin{array}{c}0.107 \\
(0.065)\end{array}$ & $\begin{array}{c}0.051 \\
(0.107)\end{array}$ & $\begin{array}{c}0.049 \\
(0.079)\end{array}$ & $\begin{array}{c}1.023 * * * \\
(0.060)\end{array}$ & $\begin{array}{c}1.067 * * * \\
(0.098)\end{array}$ & $\begin{array}{c}1.107 * * * \\
(0.064)\end{array}$ & $\begin{array}{c}0.811 * * * \\
(0.176)\end{array}$ & $\begin{array}{c}0.638 * * * \\
(0.239)\end{array}$ & $\begin{array}{c}0.754 * * * \\
(0.117)\end{array}$ \\
\hline Commodity import (\%) & $\begin{array}{l}-0.071 * \\
(0.039)\end{array}$ & $\begin{array}{l}-0.007 \\
(0.089)\end{array}$ & $\begin{array}{l}-0.020 \\
(0.029)\end{array}$ & $\begin{array}{c}0.024 \\
(0.017)\end{array}$ & $\begin{array}{c}0.030 \\
(0.022)\end{array}$ & $\begin{array}{c}0.026 * * * \\
(0.008)\end{array}$ & $\begin{array}{c}0.545 * * * \\
(0.048)\end{array}$ & $\begin{array}{c}0.567 * * * \\
(0.055)\end{array}$ & $\begin{array}{c}0.465 * * * \\
(0.025)\end{array}$ \\
\hline Relative income to US & $\begin{array}{l}0.016 \\
(0.022)\end{array}$ & $\begin{array}{c}0.106 * * \\
(0.052)\end{array}$ & $\begin{array}{l}0.021 \\
(0.015)\end{array}$ & $\begin{array}{c}0.007 \\
(0.014)\end{array}$ & $\begin{array}{l}-0.005 \\
(0.019)\end{array}$ & $\begin{array}{c}0.010 \\
(0.006)\end{array}$ & $\begin{array}{l}-0.030 \\
(0.051)\end{array}$ & $\begin{array}{c}0.022 \\
(0.059)\end{array}$ & $\begin{array}{c}-0.225 * * * \\
(0.045)\end{array}$ \\
\hline Exchange rate volatility & $\begin{array}{l}-0.002 \\
(0.008)\end{array}$ & $\begin{array}{l}-0.001 \\
(0.009)\end{array}$ & $\begin{array}{c}-0.000 \\
(0.004)\end{array}$ & $\begin{array}{l}-0.003 \\
(0.004)\end{array}$ & $\begin{array}{l}-0.003 \\
(0.005)\end{array}$ & $\begin{array}{c}0.005 \\
(0.007)\end{array}$ & $\begin{array}{c}0.013 \\
(0.014)\end{array}$ & $\begin{array}{c}0.014 \\
(0.013)\end{array}$ & $\begin{array}{c}0.015 \\
(0.014)\end{array}$ \\
\hline Inflation rate differential & $\begin{array}{c}-0.067 * * \\
(0.030)\end{array}$ & $\begin{array}{l}-0.077 \\
(0.073)\end{array}$ & $\begin{array}{c}-0.079 * * * \\
(0.029)\end{array}$ & $\begin{array}{c}0.036 \\
(0.027)\end{array}$ & $\begin{array}{c}0.035 \\
(0.028)\end{array}$ & $\begin{array}{c}0.086 * * * \\
(0.030)\end{array}$ & $\begin{array}{c}0.183 * * \\
(0.078)\end{array}$ & $\begin{array}{c}0.196 * * \\
(0.086)\end{array}$ & $\begin{array}{c}0.053 \\
(0.130)\end{array}$ \\
\hline Financial development & $\begin{array}{c}-0.091 * * * \\
(0.030)\end{array}$ & $\begin{array}{c}-0.105^{*} \\
(0.057)\end{array}$ & $\begin{array}{c}-0.050 * * \\
(0.023)\end{array}$ & $\begin{array}{l}0.038^{*} \\
(0.022)\end{array}$ & $\begin{array}{l}0.052^{*} \\
(0.026)\end{array}$ & $\begin{array}{c}0.010 \\
(0.011)\end{array}$ & $\begin{array}{c}-0.160 * * * \\
(0.047)\end{array}$ & $\begin{array}{c}-0.166 * * * \\
(0.047)\end{array}$ & $\begin{array}{l}-0.076 \\
(0.060)\end{array}$ \\
\hline Financial openness & $\begin{array}{c}-0.053 * * * \\
(0.013)\end{array}$ & $\begin{array}{c}-0.071 * * * \\
(0.019)\end{array}$ & $\begin{array}{c}-0.035 * * * \\
(0.010)\end{array}$ & $\begin{array}{c}-0.031 * * * \\
(0.007)\end{array}$ & $\begin{array}{c}-0.033 * * * \\
(0.008)\end{array}$ & $\begin{array}{l}-0.009 \\
(0.008)\end{array}$ & $\begin{array}{c}0.019 \\
(0.024)\end{array}$ & $\begin{array}{c}0.029 \\
(0.025)\end{array}$ & $\begin{array}{l}-0.024 \\
(0.022)\end{array}$ \\
\hline Post-Bretton Woods & & & & $\begin{array}{c}0.004 \\
(0.005)\end{array}$ & $\begin{array}{c}0.006 \\
(0.006)\end{array}$ & $\begin{array}{c}0.003 \\
(0.003)\end{array}$ & $\begin{array}{c}0.099 * * * \\
(0.016)\end{array}$ & $\begin{array}{c}0.090 * * * \\
(0.016)\end{array}$ & $\begin{array}{c}0.113 * * * \\
(0.016)\end{array}$ \\
\hline Pegged to U.S. dollar & $\begin{array}{c}-0.030 * * * * \\
(0.008)\end{array}$ & $\begin{array}{c}-0.032 * * * \\
(0.009)\end{array}$ & $\begin{array}{c}-0.017 * * * * \\
(0.005)\end{array}$ & $\begin{array}{l}-0.005 \\
(0.004)\end{array}$ & $\begin{array}{l}-0.006 \\
(0.004)\end{array}$ & $\begin{array}{l}-0.004 \\
(0.003)\end{array}$ & $\begin{array}{c}0.055^{* * *} * \\
(0.016)\end{array}$ & $\begin{array}{c}0.055^{* * *} * \\
(0.016)\end{array}$ & $\begin{array}{c}0.037 \\
(0.030)\end{array}$ \\
\hline Pegged to DM & $\begin{array}{c}-0.019 * * \\
(0.009)\end{array}$ & $\begin{array}{l}-0.004 \\
(0.022)\end{array}$ & $\begin{array}{c}-0.019 * * * \\
(0.005)\end{array}$ & $\begin{array}{l}-0.010 * \\
(0.006)\end{array}$ & $\begin{array}{l}-0.009 \\
(0.007)\end{array}$ & $\begin{array}{c}-0.026 * * * \\
(0.006)\end{array}$ & $\begin{array}{c}0.026 \\
(0.017)\end{array}$ & $\begin{array}{l}0.031^{*} \\
(0.017)\end{array}$ & $\begin{array}{c}0.021 \\
(0.013)\end{array}$ \\
\hline EU membership & $\begin{array}{l}-0.004 \\
(0.017)\end{array}$ & & $\begin{array}{l}-0.036 \\
(0.023)\end{array}$ & $\begin{array}{c}0.005 \\
(0.016)\end{array}$ & & $\begin{array}{c}0.010 \\
(0.012)\end{array}$ & $\begin{array}{c}-0.284 * * * \\
(0.074)\end{array}$ & & $\begin{array}{c}-0.366^{* * *} \\
(0.065)\end{array}$ \\
\hline Former U.K. colony & $\begin{array}{l}-0.004 \\
(0.013)\end{array}$ & & $\begin{array}{l}-0.026 \\
(0.017)\end{array}$ & $\begin{array}{c}0.026 \\
(0.016)\end{array}$ & & $\begin{array}{c}0.030 * * \\
(0.013)\end{array}$ & $\begin{array}{c}-0.185^{* *} * \\
(0.084)\end{array}$ & & $\begin{array}{c}-0.110 * * \\
(0.051)\end{array}$ \\
\hline Former French colony & $\begin{array}{c}-0.049 * * \\
(0.020)\end{array}$ & & $\begin{array}{c}-0.064 * * * * \\
(0.023)\end{array}$ & & & & $\begin{array}{c}-0.194 * \\
(0.116)\end{array}$ & & $\begin{array}{c}-0.332 * * * \\
(0.055)\end{array}$ \\
\hline East Asia \& Pacific & $\begin{array}{c}0.040 * * * \\
(0.015)\end{array}$ & & $\begin{array}{c}0.030^{* *} \\
(0.012)\end{array}$ & $\begin{array}{c}0.026 \\
(0.017) \\
\end{array}$ & & $\begin{array}{c}0.034 * * \\
(0.014) \\
\end{array}$ & $\begin{array}{l}-0.001 \\
(0.077) \\
\end{array}$ & & $\begin{array}{l}-0.020 \\
(0.049) \\
\end{array}$ \\
\hline$N$ & 86 & 86 & 86 & 114 & 114 & 114 & 174 & 174 & 174 \\
\hline \# of economies & 16 & 16 & 16 & 18 & 18 & 18 & 29 & 29 & 29 \\
\hline Overall R2 & 0.83 & 0.03 & $\cdot$ & 0.95 & 0.94 & . & 0.87 & 0.48 & . \\
\hline W/in R2 & 0.60 & 0.67 & . & 0.68 & 0.68 & . & 0.70 & 0.70 & . \\
\hline B/w R2 & 0.82 & 0.03 & . & 0.98 & 0.96 & . & 0.72 & 0.52 & \\
\hline
\end{tabular}


Table 4: Estimated Major Currency Weights in Implicit Currency Baskets in Europe and Asia-Oceania

(a) European countries

\begin{tabular}{|c|c|c|c|c|c|c|}
\hline Germany & 1972 & 1979 & 1987 & 1995 & 2005 & 2012 \\
\hline USD & 0.0 & 0.0 & 0.0 & 0.0 & 0.0 & 0.0 \\
\hline DM-FF/ EURO & 100.0 & 100.0 & 100.0 & 100.0 & 100.0 & 100.0 \\
\hline UKP & 0.0 & 0.0 & 0.0 & 0.0 & 0.0 & 0.0 \\
\hline YEN & 0.0 & 0.0 & 0.0 & 0.0 & 0.0 & 0.0 \\
\hline Belgium & 1972 & 1979 & 1987 & 1995 & 2005 & 2012 \\
\hline USD & 40.0 & 1.7 & 4.9 & 19.8 & 0.0 & 0.0 \\
\hline DM-FF/ EURO & 16.9 & 97.8 & 93.9 & 80.0 & 100.0 & 100.0 \\
\hline UKP & 24.1 & 0.5 & 1.2 & 0.0 & 0.0 & 0.0 \\
\hline YEN & 19.1 & 0.0 & 0.0 & 0.2 & 0.0 & 0.0 \\
\hline Denmark & 1972 & 1979 & 1987 & 1995 & 2005 & 2012 \\
\hline USD & 63.7 & 14.1 & 10.7 & 13.4 & 3.9 & 0.7 \\
\hline DM-FF/ EURO & 0.0 & 84.9 & 89.3 & 86.6 & 96.1 & 99.3 \\
\hline UKP & 20.3 & 0.9 & 0.0 & 0.0 & 0.0 & 0.0 \\
\hline YEN & 16.0 & 0.0 & 0.0 & 0.0 & 0.0 & 0.0 \\
\hline France & 1972 & 1979 & 1987 & 1995 & 2005 & 2012 \\
\hline USD & 0.0 & 0.0 & 0.0 & 0.0 & 0.0 & 0.0 \\
\hline DM-FF/ EURO & 100.0 & 100.0 & 100.0 & 100.0 & 100.0 & 100.0 \\
\hline UKP & 0.0 & 0.0 & 0.0 & 0.0 & 0.0 & 0.0 \\
\hline YEN & 0.0 & 0.0 & 0.0 & 0.0 & 0.0 & 0.0 \\
\hline Italy & 1972 & 1979 & 1987 & 1995 & 2005 & 2012 \\
\hline USD & 84.9 & 89.1 & 14.8 & 28.2 & 0.0 & 0.0 \\
\hline DM-FF/ EURO & 3.8 & 8.0 & 85.2 & 0.0 & 100.0 & 100.0 \\
\hline UKP & 0.0 & 2.9 & 0.0 & 71.8 & 0.0 & 0.0 \\
\hline YEN & 11.3 & 0.0 & 0.0 & 0.0 & 0.0 & 0.0 \\
\hline Netherlands & 1972 & 1979 & 1987 & 1995 & 2005 & 2012 \\
\hline USD & 68.8 & 5.1 & 6.0 & 6.5 & 0.0 & 0.0 \\
\hline DM-FF/ EURO & 6.8 & 94.6 & 91.2 & 93.5 & 100.0 & 100.0 \\
\hline UKP & 0.0 & 0.3 & 2.8 & 0.0 & 0.0 & 0.0 \\
\hline YEN & 24.3 & 0.0 & 0.0 & 0.0 & 0.0 & 0.0 \\
\hline U.K. & 1972 & 1979 & 1987 & 1995 & 2005 & 2012 \\
\hline USD & 0.0 & 0.0 & 0.0 & 0.0 & 0.0 & 0.0 \\
\hline DM-FF/ EURO & 0.0 & 0.0 & 0.0 & 0.0 & 0.0 & 0.0 \\
\hline UKP & 100.0 & 100.0 & 100.0 & 100.0 & 100.0 & 100.0 \\
\hline YEN & 0.0 & 0.0 & 0.0 & 0.0 & 0.0 & 0.0 \\
\hline
\end{tabular}

(b) Asia-Oceania countries

\begin{tabular}{lcccccc}
\hline Japan & $\mathbf{1 9 7 2}$ & $\mathbf{1 9 7 9}$ & $\mathbf{1 9 8 7}$ & $\mathbf{1 9 9 5}$ & $\mathbf{2 0 0 5}$ & $\mathbf{2 0 1 2}$ \\
\hline USD & 0.0 & 0.0 & 0.0 & 0.0 & 0.0 & 0.0 \\
DM-FF/ EURO & 0.0 & 0.0 & 0.0 & 0.0 & 0.0 & 0.0 \\
UKP & 0.0 & 0.0 & 0.0 & 0.0 & 0.0 & 0.0 \\
YEN & 100.0 & 100.0 & 100.0 & 100.0 & 100.0 & 100.0 \\
\hline Australia & $\mathbf{1 9 7 2}$ & $\mathbf{1 9 7 9}$ & $\mathbf{1 9 8 7}$ & $\mathbf{1 9 9 5}$ & $\mathbf{2 0 0 5}$ & $\mathbf{2 0 1 2}$ \\
\hline USD & 24.3 & 97.7 & 65.2 & 98.7 & 77.5 & 11.5 \\
DM-FF/ EURO & 3.1 & 0.7 & 32.2 & 0.0 & 22.5 & 83.9 \\
UKP & 64.9 & 0.5 & 1.2 & 1.3 & 0.0 & 4.6 \\
YEN & 7.7 & 1.1 & 1.4 & 0.0 & 0.0 & 0.0 \\
\hline New Zealand & $\mathbf{1 9 7 2}$ & $\mathbf{1 9 7 9}$ & $\mathbf{1 9 8 7}$ & $\mathbf{1 9 9 5}$ & $\mathbf{2 0 0 5}$ & $\mathbf{2 0 1 2}$ \\
\hline USD & 25.2 & 80.4 & 94.4 & 93.5 & 45.4 & 11.3 \\
DM-FF/ EURO & 2.2 & 0.0 & 0.0 & 5.5 & 54.6 & 71.3 \\
UKP & 56.2 & 13.5 & 5.6 & 0.0 & 0.0 & 17.4 \\
YEN & 16.4 & 6.1 & 0.0 & 1.0 & 0.0 & 0.0 \\
\hline India & $\mathbf{1 9 7 2}$ & $\mathbf{1 9 7 9}$ & $\mathbf{1 9 8 7}$ & $\mathbf{1 9 9 5}$ & $\mathbf{2 0 0 5}$ & $\mathbf{2 0 1 2}$ \\
\hline USD & 4.5 & 39.3 & 64.2 & 100.0 & 84.1 & 64.2 \\
DM-FF/ EURO & 7.8 & 8.3 & 6.4 & 0.0 & 0.4 & 35.8 \\
UKP & 87.7 & 52.4 & 29.4 & 0.0 & 0.4 & 0.0 \\
YEN & 0.0 & 0.0 & 0.0 & 0.0 & 15.2 & 0.0 \\
\hline Indonesia & $\mathbf{1 9 7 2}$ & $\mathbf{1 9 7 9}$ & $\mathbf{1 9 8 7}$ & $\mathbf{1 9 9 5}$ & $\mathbf{2 0 0 5}$ & $\mathbf{2 0 1 2}$ \\
\hline USD & 90.0 & 97.3 & 100.0 & 99.6 & 91.8 & 57.0 \\
DM-FF/ EURO & 0.0 & 0.0 & 0.0 & 0.0 & 8.2 & 37.7 \\
UKP & 0.0 & 0.0 & 0.0 & 0.0 & 0.0 & 5.4 \\
YEN & 10.0 & 2.7 & 0.0 & 0.4 & 0.0 & 0.0 \\
\hline Korea & $\mathbf{1 9 7 2}$ & $\mathbf{1 9 7 9}$ & $\mathbf{1 9 8 7}$ & $\mathbf{1 9 9 5}$ & $\mathbf{2 0 0 5}$ & $\mathbf{2 0 1 2}$ \\
\hline USD & 100.0 & 100.0 & 95.7 & 98.8 & 47.8 & 17.3 \\
DM-FF/ EURO & 0.0 & 0.0 & 4.3 & 0.0 & 0.0 & 82.7 \\
UKP & 0.0 & 0.0 & 0.0 & 0.0 & 0.0 & 0.0 \\
YEN & 0.0 & 0.0 & 0.0 & 1.2 & 52.2 & 0.0 \\
\hline Thailand & $\mathbf{1 9 7 2}$ & $\mathbf{1 9 7 9}$ & $\mathbf{1 9 8 7}$ & $\mathbf{1 9 9 5}$ & $\mathbf{2 0 0 5}$ & $\mathbf{2 0 1 2}$ \\
\hline USD & 100.0 & 100.0 & 98.8 & 80.8 & 66.5 & 90.4 \\
DM-FF/ EURO & 0.0 & 0.0 & 0.0 & 7.5 & 7.2 & 0.0 \\
UKP & 0.0 & 0.0 & 0.5 & 0.7 & 0.0 & 0.0 \\
YEN & 0.0 & 0.0 & 0.7 & 11.0 & 26.3 & 9.6 \\
\hline & & & & & & \\
\hline
\end{tabular}


Table 5: Trade Shares with Major-Currency-Zone Countries in Europe and Asia-Oceania

(a) European countries

\begin{tabular}{|c|c|c|c|c|c|c|}
\hline Germany & 1972 & 1979 & 1987 & 1995 & 2005 & 2012 \\
\hline USD & 55.22 & 38.40 & 28.75 & 37.67 & 29.15 & 23.03 \\
\hline DM-FF/ EURO & 16.60 & 38.38 & 44.01 & 30.28 & 58.48 & 66.77 \\
\hline UKP & 7.55 & 7.57 & 9.88 & 16.84 & 7.39 & 7.20 \\
\hline YEN & 7.41 & 2.23 & 5.54 & 4.71 & 3.85 & 1.86 \\
\hline Belgium & 1972 & 1979 & 1987 & 1995 & 2005 & 2012 \\
\hline USD & 37.31 & 24.88 & 18.92 & 22.71 & 20.11 & 19.19 \\
\hline DM-FF/ EURO & 46.82 & 62.89 & 66.09 & 55.84 & 68.84 & 70.97 \\
\hline UKP & 7.39 & 8.91 & 9.69 & 14.84 & 7.61 & 7.04 \\
\hline YEN & 6.51 & 1.28 & 2.74 & 2.12 & 2.66 & 1.68 \\
\hline Denmark & 1972 & 1979 & 1987 & 1995 & 2005 & 2012 \\
\hline USD & 48.87 & 28.82 & 26.54 & 33.48 & 19.58 & 20.75 \\
\hline DM-FF/ EURO & 20.92 & 47.40 & 46.08 & 41.97 & 68.17 & 67.80 \\
\hline UKP & 17.54 & 14.00 & 12.82 & 15.69 & 7.58 & 8.51 \\
\hline YEN & 6.65 & 2.33 & 6.93 & 3.73 & 2.61 & 1.37 \\
\hline France & 1972 & 1979 & 1987 & 1995 & 2005 & 2012 \\
\hline USD & 44.22 & 40.56 & 25.93 & 33.72 & 24.08 & 21.99 \\
\hline DM-FF/ EURO & 26.52 & 34.97 & 44.75 & 29.20 & 63.41 & 68.28 \\
\hline UKP & 8.14 & 7.76 & 9.26 & 19.98 & 7.25 & 6.78 \\
\hline YEN & 4.86 & 1.61 & 3.86 & 3.20 & 2.65 & 1.78 \\
\hline Italy & 1972 & 1979 & 1987 & 1995 & 2005 & 2012 \\
\hline USD & 41.81 & 36.44 & 28.18 & 36.13 & 30.91 & 27.64 \\
\hline DM-FF/ EURO & 38.85 & 47.06 & 51.47 & 44.68 & 59.11 & 63.16 \\
\hline UKP & 6.60 & 6.23 & 7.65 & 10.26 & 5.61 & 5.19 \\
\hline YEN & 3.33 & 1.38 & 3.32 & 2.85 & 2.85 & 1.91 \\
\hline Netherlands & 1972 & 1979 & 1987 & 1995 & 2005 & 2012 \\
\hline USD & 29.33 & 28.11 & 20.38 & 27.08 & 26.88 & 24.89 \\
\hline DM-FF/ EURO & 40.84 & 44.01 & 48.58 & 40.37 & 60.32 & 63.63 \\
\hline UKP & 8.19 & 8.78 & 10.24 & 15.78 & 7.80 & 8.13 \\
\hline YEN & 2.52 & 1.44 & 3.17 & 2.75 & 2.92 & 1.76 \\
\hline U.K. & 1972 & 1979 & 1987 & 1995 & 2005 & 2012 \\
\hline USD & 59.23 & 46.69 & 35.26 & 39.94 & 31.72 & 29.30 \\
\hline DM-FF/ EURO & 14.21 & 40.30 & 48.43 & 37.39 & 57.53 & 63.38 \\
\hline UKP & 12.02 & 2.77 & 2.82 & 7.82 & 0.17 & 0.87 \\
\hline YEN & 6.65 & 2.71 & 5.76 & 4.78 & 4.11 & 1.86 \\
\hline
\end{tabular}

(b) Asia-Oceania countries

\begin{tabular}{lcccccc}
\hline Japan & $\mathbf{1 9 7 2}$ & $\mathbf{1 9 7 9}$ & $\mathbf{1 9 8 7}$ & $\mathbf{1 9 9 5}$ & $\mathbf{2 0 0 5}$ & $\mathbf{2 0 1 2}$ \\
\hline USD & 70.18 & 74.45 & 72.49 & 76.08 & 72.19 & 66.99 \\
DM-FF/ EURO & 5.48 & 13.75 & 13.89 & 9.93 & 14.65 & 25.41 \\
UKP & 12.72 & 3.80 & 4.17 & 5.69 & 2.07 & 2.52 \\
YEN & 2.08 & 0.67 & 1.64 & 1.34 & 5.31 & 0.50 \\
\hline Australia & $\mathbf{1 9 7 2}$ & $\mathbf{1 9 7 9}$ & $\mathbf{1 9 8 7}$ & $\mathbf{1 9 9 5}$ & $\mathbf{2 0 0 5}$ & $\mathbf{2 0 1 2}$ \\
\hline USD & 38.38 & 46.28 & 46.75 & 56.03 & 52.05 & 52.80 \\
DM-FF/ EURO & 8.29 & 14.83 & 14.94 & 9.24 & 19.21 & 23.97 \\
UKP & 22.48 & 9.44 & 7.04 & 8.46 & 3.82 & 4.73 \\
YEN & 25.26 & 22.52 & 23.82 & 19.93 & 20.59 & 13.82 \\
\hline New Zealand & $\mathbf{1 9 7 2}$ & $\mathbf{1 9 7 9}$ & $\mathbf{1 9 8 7}$ & $\mathbf{1 9 9 5}$ & $\mathbf{2 0 0 5}$ & $\mathbf{2 0 1 2}$ \\
\hline USD & 32.98 & 51.17 & 45.11 & 60.95 & 57.43 & 50.31 \\
DM-FF/ EURO & 6.45 & 11.63 & 18.03 & 7.85 & 20.56 & 34.30 \\
UKP & 41.97 & 16.20 & 10.61 & 9.15 & 3.91 & 4.94 \\
YEN & 13.49 & 14.43 & 18.89 & 15.60 & 14.01 & 7.01 \\
\hline India & $\mathbf{1 9 7 2}$ & $\mathbf{1 9 7 9}$ & $\mathbf{1 9 8 7}$ & $\mathbf{1 9 9 5}$ & $\mathbf{2 0 0 5}$ & $\mathbf{2 0 1 2}$ \\
\hline USD & 46.58 & 46.56 & 42.23 & 57.78 & 50.99 & 65.41 \\
DM-FF/ EURO & 8.81 & 18.46 & 19.82 & 13.59 & 21.36 & 26.39 \\
UKP & 14.12 & 9.93 & 8.67 & 9.95 & 3.72 & 3.36 \\
YEN & 11.71 & 9.32 & 12.16 & 7.78 & 5.61 & 2.88 \\
\hline Indonesia & $\mathbf{1 9 7 2}$ & $\mathbf{1 9 7 9}$ & $\mathbf{1 9 8 7}$ & $\mathbf{1 9 9 5}$ & $\mathbf{2 0 0 5}$ & $\mathbf{2 0 1 2}$ \\
\hline USD & 28.53 & 38.84 & 40.91 & 53.50 & 55.24 & 53.83 \\
DM-FF/ EURO & 7.06 & 13.85 & 12.06 & 11.13 & 14.57 & 25.97 \\
UKP & 8.03 & 1.97 & 2.37 & 5.29 & 1.43 & 2.60 \\
YEN & 45.14 & 40.89 & 39.62 & 26.25 & 25.77 & 14.41 \\
\hline Korea & $\mathbf{1 9 7 2}$ & $\mathbf{1 9 7 9}$ & $\mathbf{1 9 8 7}$ & $\mathbf{1 9 9 5}$ & $\mathbf{2 0 0 5}$ & $\mathbf{2 0 1 2}$ \\
\hline USD & 47.68 & 53.52 & 53.08 & 60.59 & 65.23 & 64.65 \\
DM-FF/ EURO & 4.93 & 12.02 & 11.75 & 8.95 & 14.06 & 19.14 \\
UKP & 6.80 & 3.74 & 3.44 & 4.70 & 1.75 & 2.39 \\
YEN & 35.74 & 28.87 & 26.07 & 19.53 & 14.67 & 9.94 \\
\hline Thailand & $\mathbf{1 9 7 2}$ & $\mathbf{1 9 7 9}$ & $\mathbf{1 9 8 7}$ & $\mathbf{1 9 9 5}$ & $\mathbf{2 0 0 5}$ & $\mathbf{2 0 1 2}$ \\
\hline USD & 38.65 & 44.39 & 49.32 & 47.20 & 58.63 & 54.31 \\
DM-FF/ EURO & 7.98 & 22.75 & 16.30 & 9.22 & 13.74 & 23.54 \\
UKP & 12.43 & 3.78 & 4.28 & 4.19 & 1.95 & 3.02 \\
YEN & 32.70 & 24.18 & 24.38 & 23.27 & 21.31 & 15.47 \\
\hline & & & & & & \\
\hline
\end{tabular}


Table 6: Effects of the Estimated Currency Weight and the Trade Share with Major-Currency-Zone Countries on the Share of the U.S. Dollar, the DM or the Yen Used for Trade Invoicing in 1970 - 1998:

Using Data for Non-Major Currency Economies

\begin{tabular}{cccc}
\hline Currency Weight & U.S. Dollar & DM & Japanese Yen \\
U.S. Dollar weight & $(1)$ & $(2)$ & $(3)$ \\
DM weight & 0.031 & $-0.013 * *$ & 0.012 \\
& $(0.027)$ & $(0.006)$ & $(0.017)$ \\
Japanese Yen weight & -0.017 & $0.012 * *$ & -0.008 \\
& $(0.028)$ & $(0.007)$ & $(0.010)$ \\
& 0.027 & $0.040 * * *$ & 0.029 \\
Trade Share with Major- & $(0.066)$ & $(0.015)$ & $(0.065)$ \\
Currency-Zone Countries & U.S. Dollar & DM & Japanese Yen \\
U.S. Dollar zone & $(1)$ & $(2)$ & $(3)$ \\
DM zone & $0.237 * * *$ & $-0.027 *$ & 0.042 \\
& $(0.073)$ & $(0.016)$ & $(0.036)$ \\
Japanese Yen zone & $-0.352 * * *$ & 0.025 & -0.020 \\
& $(0.107)$ & $(0.024)$ & $(0.033)$ \\
& $-0.529 * * *$ & -0.022 & $-0.241 * * *$ \\
& $(0.171)$ & $(0.035)$ & $(0.078)$ \\
\hline
\end{tabular}

Note: $* p<0.1 ; * * p<0.05 ; * * * p<0.01$. 
Table 7: Tests of Similarity in the Determinants of Major-Currency Shares for Export Invoicing: Using Data for Non-Major Currency Economies

\begin{tabular}{|c|c|c|c|c|c|c|c|c|c|}
\hline & & & $\begin{array}{c}\text { U.S. } \\
\text { Dollar }\end{array}$ & $\begin{array}{c}\text { Japanese } \\
\text { Yen }\end{array}$ & $\begin{array}{c}\text { Deutsche } \\
\text { Mark }\end{array}$ & $\begin{array}{c}\text { U.K. } \\
\text { Pound }\end{array}$ & $\begin{array}{c}\text { French } \\
\text { Franc } \\
\end{array}$ & $\begin{array}{c}\text { Italian } \\
\text { Lira } \\
\end{array}$ & $\begin{array}{c}\text { Swiss } \\
\text { Franc } \\
\end{array}$ \\
\hline \multirow[t]{2}{*}{1} & Seven & Chi Sq. & 2430.58 & 281.92 & 14.79 & 13.34 & 7.32 & 3.47 & 3.55 \\
\hline & Currencies & $p$-value & $0.000 * * *$ & $0.000 * * *$ & $0.063^{*}$ & 0.101 & 0.396 & 0.901 & 0.895 \\
\hline \multirow[t]{2}{*}{2} & Six & Chi Sq. & & 318.97 & 114.41 & 87.31 & 14.30 & 14.45 & 4.42 \\
\hline & Currencies & $p$-value & & $0.000 * * *$ & $0.000 * * *$ & $0.000 * * *$ & $0.046 * *$ & 0.071 & 0.817 \\
\hline \multirow[t]{2}{*}{3} & Five & Chi Sq. & & & 90.75 & 63.89 & 42.12 & 32.94 & 2.91 \\
\hline & Currencies & $p$-value & & & $0.000 * * *$ & $0.000 * * *$ & $0.000 * * *$ & $0.000 * * *$ & 0.940 \\
\hline \multirow[t]{2}{*}{4} & Four & Chi Sq. & & & & 71.34 & 29.41 & 7.00 & 30.20 \\
\hline & Currencies & $p$-value & & & & $0.000 * * *$ & $0.000 * * *$ & 0.536 & $0.000 * * *$ \\
\hline
\end{tabular}

Note: $* p<0.1 ; * * p<0.05 ; * * * p<0.01$. 
Table 8: Determinants of the Major Currency Share for Export Invoicing: Using Data for Non-Major Currency Economies, 1970-1998

\begin{tabular}{|c|c|c|c|}
\hline & $\begin{array}{c}\text { U.S. Dollar Dummy } \\
\text { against } \\
\text { Six Others } \\
(1) \\
\end{array}$ & $\begin{array}{c}\text { Yen Dummy } \\
\text { against } \\
\text { Five Others } \\
(2) \\
\end{array}$ & $\begin{array}{c}\text { DM Dummy } \\
\text { against } \\
\text { Four Others } \\
(3) \\
\end{array}$ \\
\hline \multirow[t]{2}{*}{ Share of export } & $0.502 * * *$ & $0.683 * * *$ & $0.615^{* * *}$ \\
\hline & $(0.038)$ & $(0.016)$ & $(0.027)$ \\
\hline \multirow[t]{2}{*}{ Commodity export } & -0.008 & 0.023 & $0.044 * * *$ \\
\hline & $(0.050)$ & $(0.017)$ & $(0.012)$ \\
\hline \multirow[t]{2}{*}{ Relative income to U.S. } & $0.122 * * *$ & 0.007 & -0.008 \\
\hline & $(0.028)$ & $(0.011)$ & $(0.010)$ \\
\hline \multirow[t]{2}{*}{ Exchange rate volatility } & -0.000 & -0.000 & -0.000 \\
\hline & $(0.000)$ & $(0.000)$ & $(0.000)$ \\
\hline \multirow[t]{2}{*}{ Inflation rate differential } & 0.054 & 0.024 & 0.031 \\
\hline & $(0.048)$ & $(0.019)$ & $(0.025)$ \\
\hline \multirow[t]{2}{*}{ Financial development } & $0.052 * * *$ & -0.002 & 0.032 \\
\hline & $(0.017)$ & $(0.018)$ & $(0.019)$ \\
\hline \multirow[t]{2}{*}{ Financial openness } & -0.019 & $-0.017 * * *$ & $-0.007 * *$ \\
\hline & $(0.008)^{* *}$ & $(0.003)$ & $(0.003)$ \\
\hline \multirow[t]{2}{*}{ Post-Bretton Woods } & -0.009 & -0.005 & $-0.016^{* * *}$ \\
\hline & $(0.008)$ & $(0.003)$ & $(0.003)$ \\
\hline \multirow[t]{2}{*}{ Trade share with USD zone } & $-0.120 * * *$ & 0.010 & 0.015 \\
\hline & $(0.042)$ & $(0.015)$ & $(0.015)$ \\
\hline \multirow[t]{2}{*}{ Peg to DM } & $0.023 * *$ & 0.000 & $0.005^{*}$ \\
\hline & $(0.009)$ & $(0.003)$ & $(0.003)$ \\
\hline \multirow[t]{2}{*}{ Currency dummy (CD) } & $0.196 * * *$ & $-0.029 *$ & $0.093 * * *$ \\
\hline & $(0.039)$ & $(0.017)$ & $(0.020)$ \\
\hline \multirow[t]{2}{*}{$\mathrm{CD} \times$ trade share } & $0.451 * * *$ & $-0.501 * * *$ & 0.001 \\
\hline & $(0.089)$ & $(0.044)$ & $(0.049)$ \\
\hline \multirow[t]{2}{*}{ CD $x$ commodity trade } & $0.387 * * *$ & $-0.094 * * *$ & $-0.118 * * *$ \\
\hline & $(0.038)$ & $(0.018)$ & $(0.018)$ \\
\hline \multirow[t]{2}{*}{$\mathrm{CD} \times$ relative income } & $-0.653 * * *$ & $0.040 * * *$ & 0.003 \\
\hline & $(0.028)$ & $(0.014)$ & $(0.014)$ \\
\hline \multirow[t]{2}{*}{ CD $x$ exchange rate volatility } & -0.000 & $0.000 *$ & -0.000 \\
\hline & $(0.000)$ & $(0.000)$ & $(0.000)$ \\
\hline \multirow[t]{2}{*}{$\mathrm{CD} \times$ inflation rate differential } & 0.040 & $-0.068 * *$ & 0.041 \\
\hline & $(0.078)$ & $(0.033)$ & $(0.047)$ \\
\hline \multirow[t]{2}{*}{ CD $\mathrm{x}$ financial development } & $-0.110 * *$ & $-0.077 * * *$ & -0.046 \\
\hline & $(0.048)$ & $(0.023)$ & $(0.032)$ \\
\hline \multirow[t]{2}{*}{ CD $x$ financial openness } & $-0.048 * * *$ & 0.001 & 0.004 \\
\hline & $(0.018)$ & $(0.009)$ & $(0.008)$ \\
\hline \multirow[t]{2}{*}{ CD $x$ Trade share with USD zone } & $0.760 * * *$ & $0.044 * *$ & $-0.121 * * *$ \\
\hline & $(0.051)$ & $(0.022)$ & $(0.024)$ \\
\hline$N$ & 776 & 569 & 479 \\
\hline \# of economies & 32 & 26 & 20 \\
\hline Overall R2 & 0.94 & 0.82 & 0.87 \\
\hline W/in R2 & 0.94 & 0.83 & 0.87 \\
\hline B/w R2 & 0.91 & 0.63 & 0.86 \\
\hline F-stat, Int. & 2430.58 & 318.97 & 90.75 \\
\hline F-stat, p & 0.000 & 0.000 & 0.000 \\
\hline
\end{tabular}

Notes: $* p<0.1 ; * * p<0.05$; $* * * p<0.01$. The estimates on the dummies for EU, former British or French colonies, and East Asia are not shown to conserve space. 
Table 9: Determinants of the Home Currency Share for Trade Invoicing: Using Data for Major Currency Countries Excluding the U.S., 1970-1998

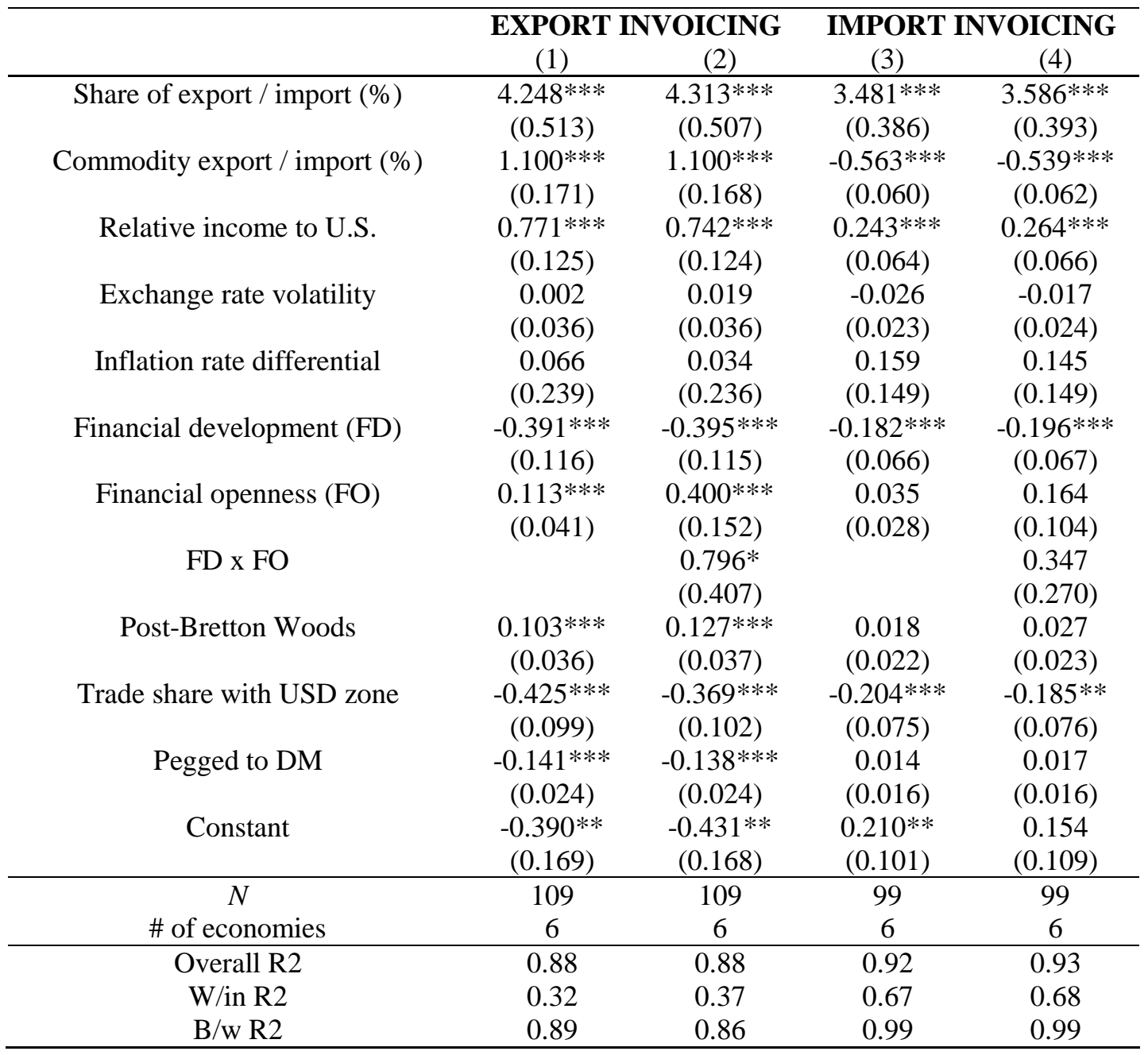

Notes: $* p<0.1 ; * * p<0.05$; *** $p<0.01$. "Major currencies" include yen, DM, FF, UKP, SF, and IL. 
Figure 1: Shares of Major Currencies Used for Trade Invoicing in Japan and Germany

\section{(a) Japan}

Japan -- expport invoicing

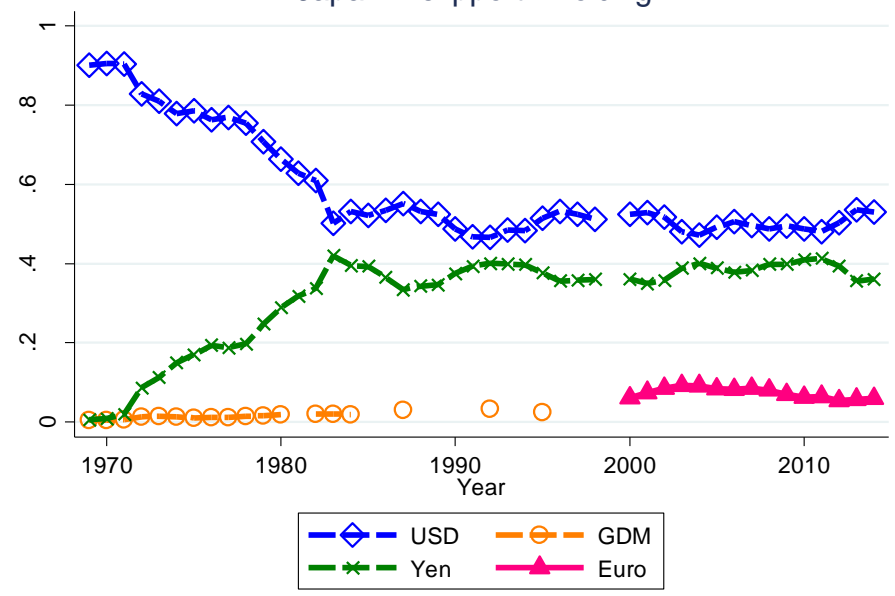

Japan -- impport invoicing

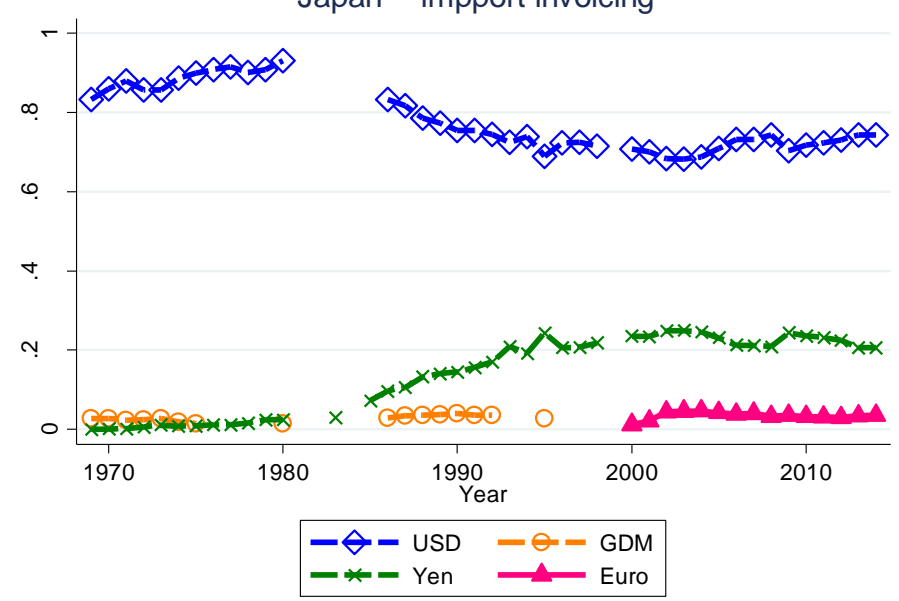

(b) Germany

Germany -- expport invoicing

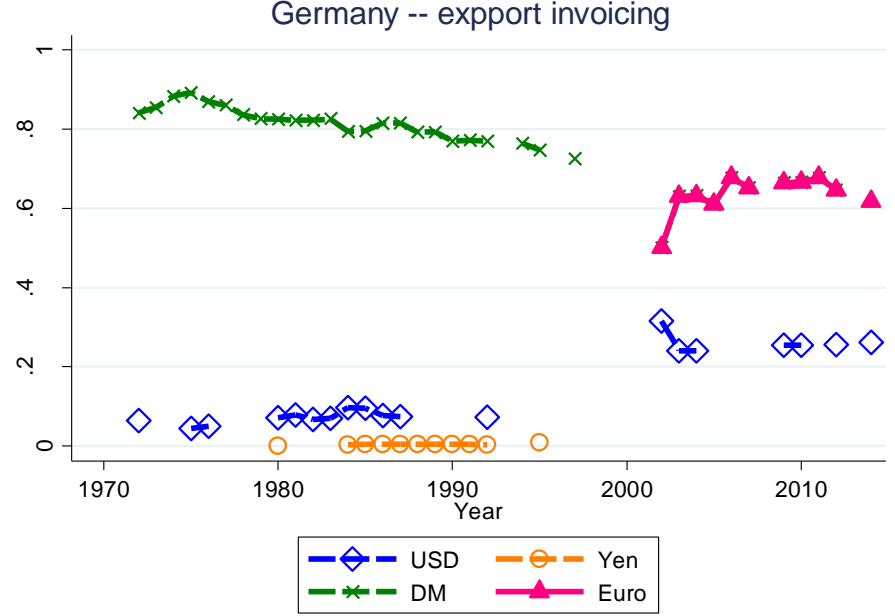

Germany -- impport invoicing

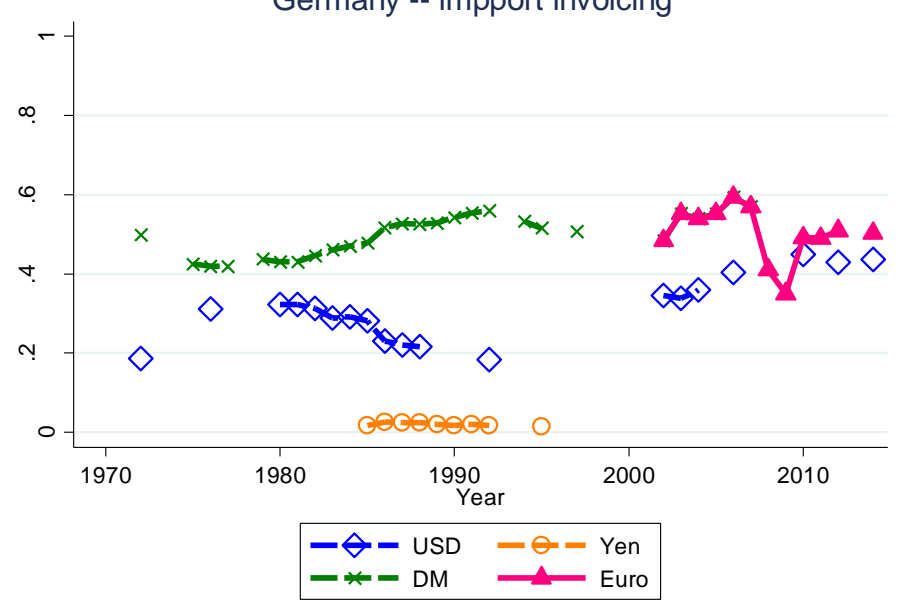


Figure 2: Major Currency Share and Export Share for Major-Currency Country's Trade Partners

(a) Export share with Japan and yen invoicing

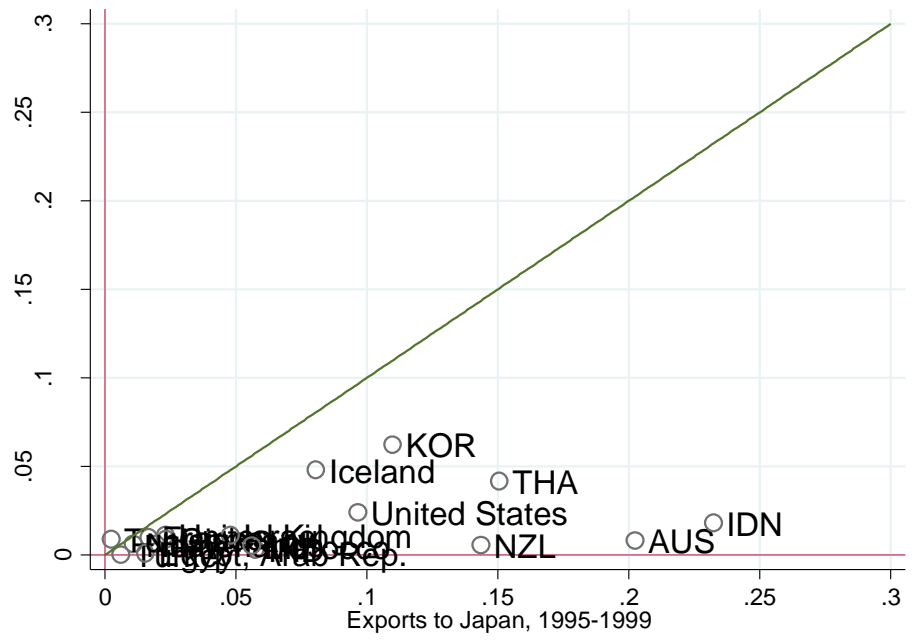

(b) Export share with the U.S. and U.S. dollar invoicing

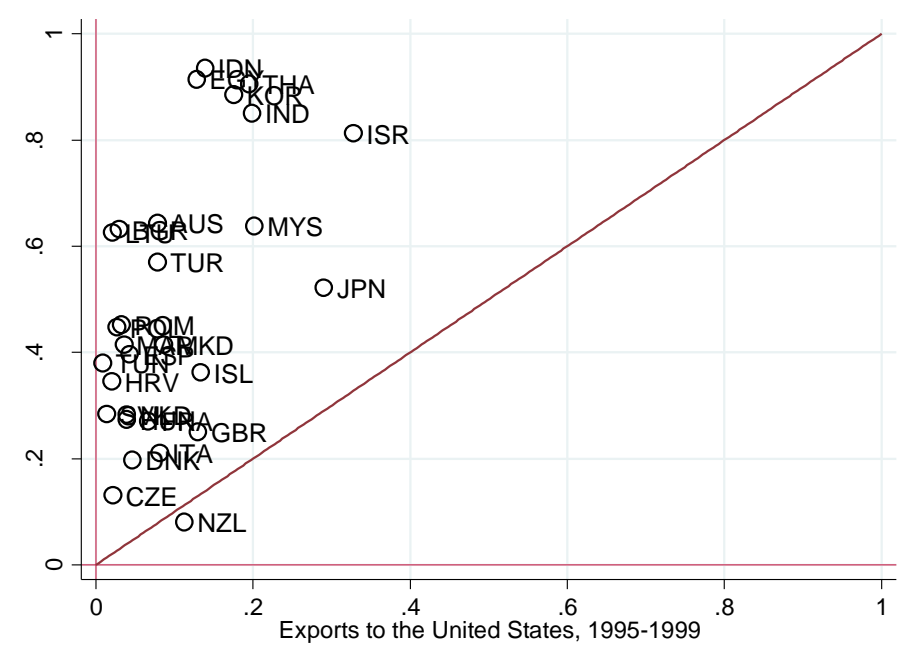

(c) Export share with Germany and DM invoicing

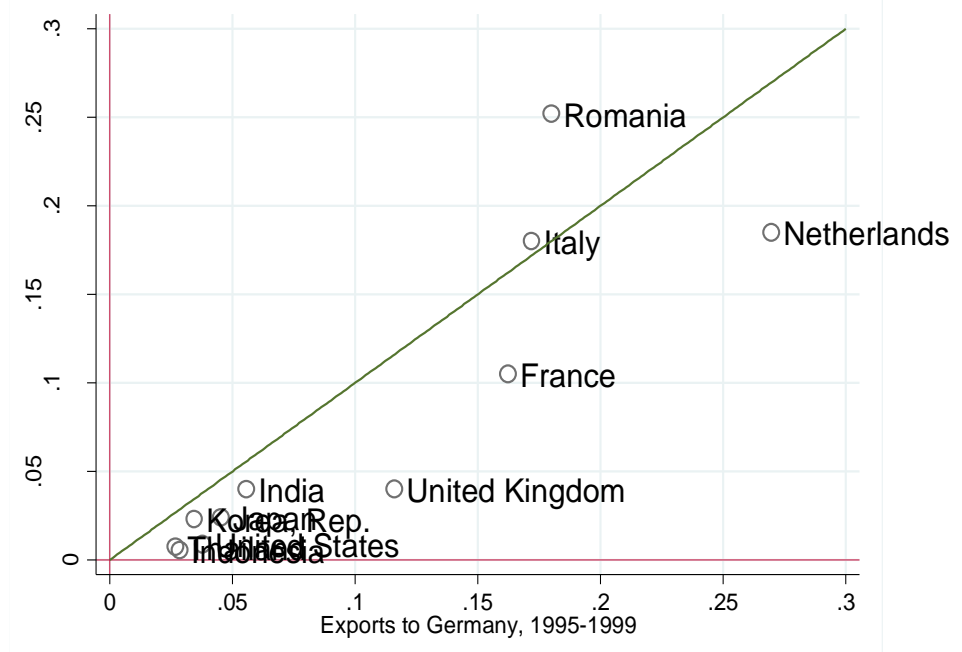

(d) Export share with the Euro Area and euro invoicing

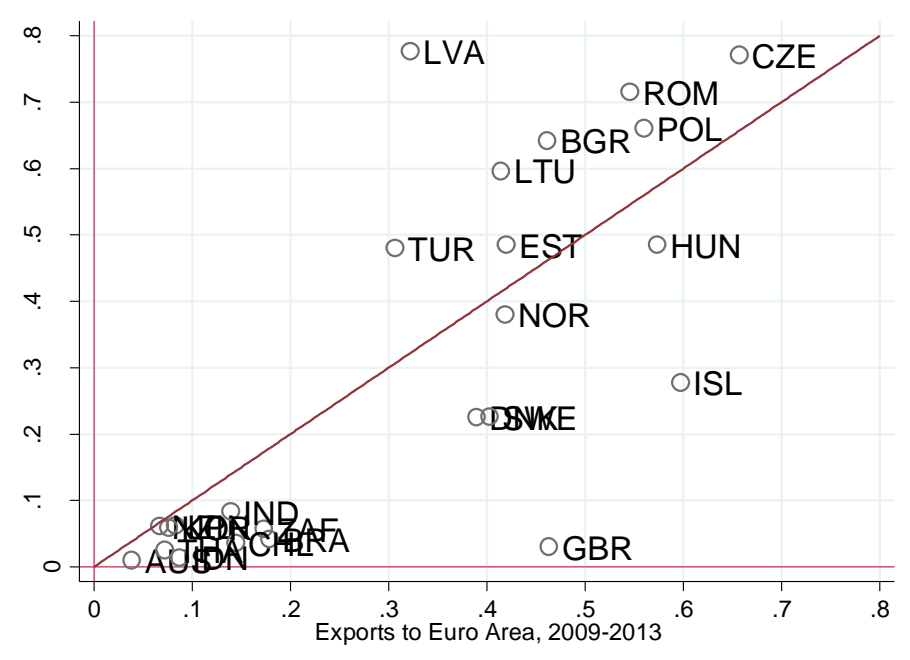


Figure 3-1: Yen Invoicing and the Export Share with Japan by Several Trade Partners of Japan, 1970 - 2013
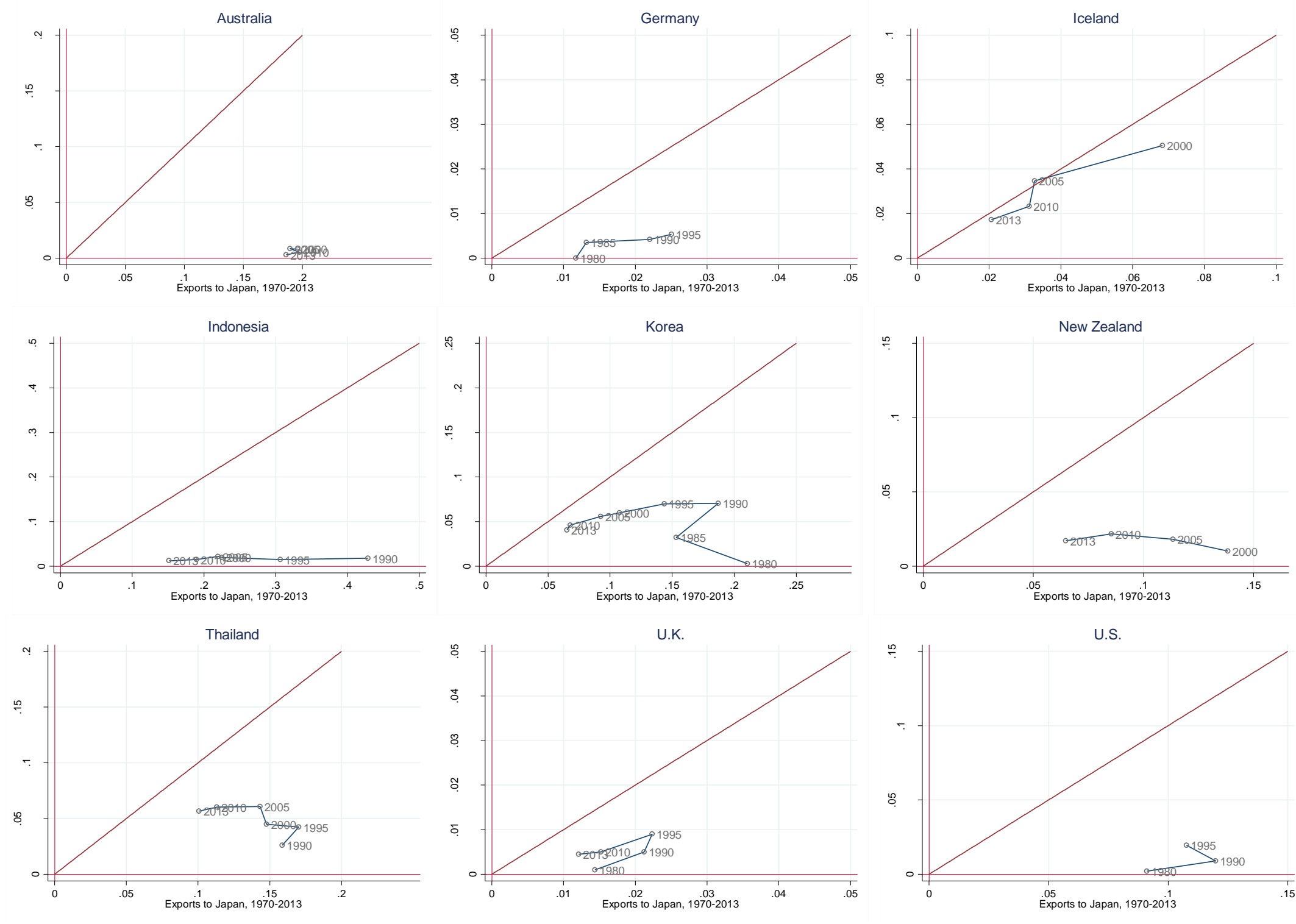
Figure 3-2: DM Invoicing and the Export Share with Germany by Several Trade Partners of Germany, 1970 - 1999
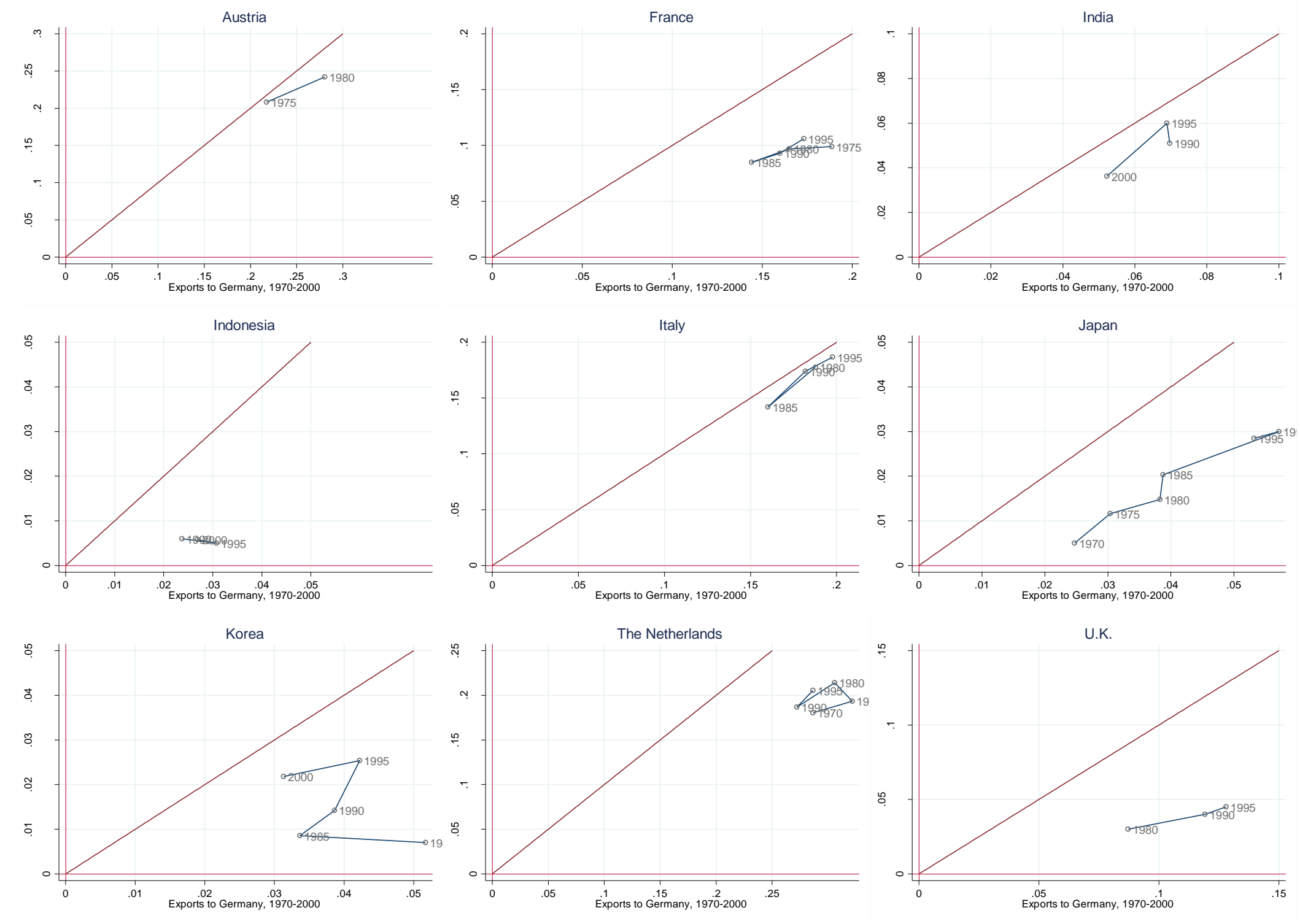

53 
Figure 3-3: Euro Invoicing and the Export Share with the Euro Area by Trade Partners of the Euro Area, 1999 - 2013
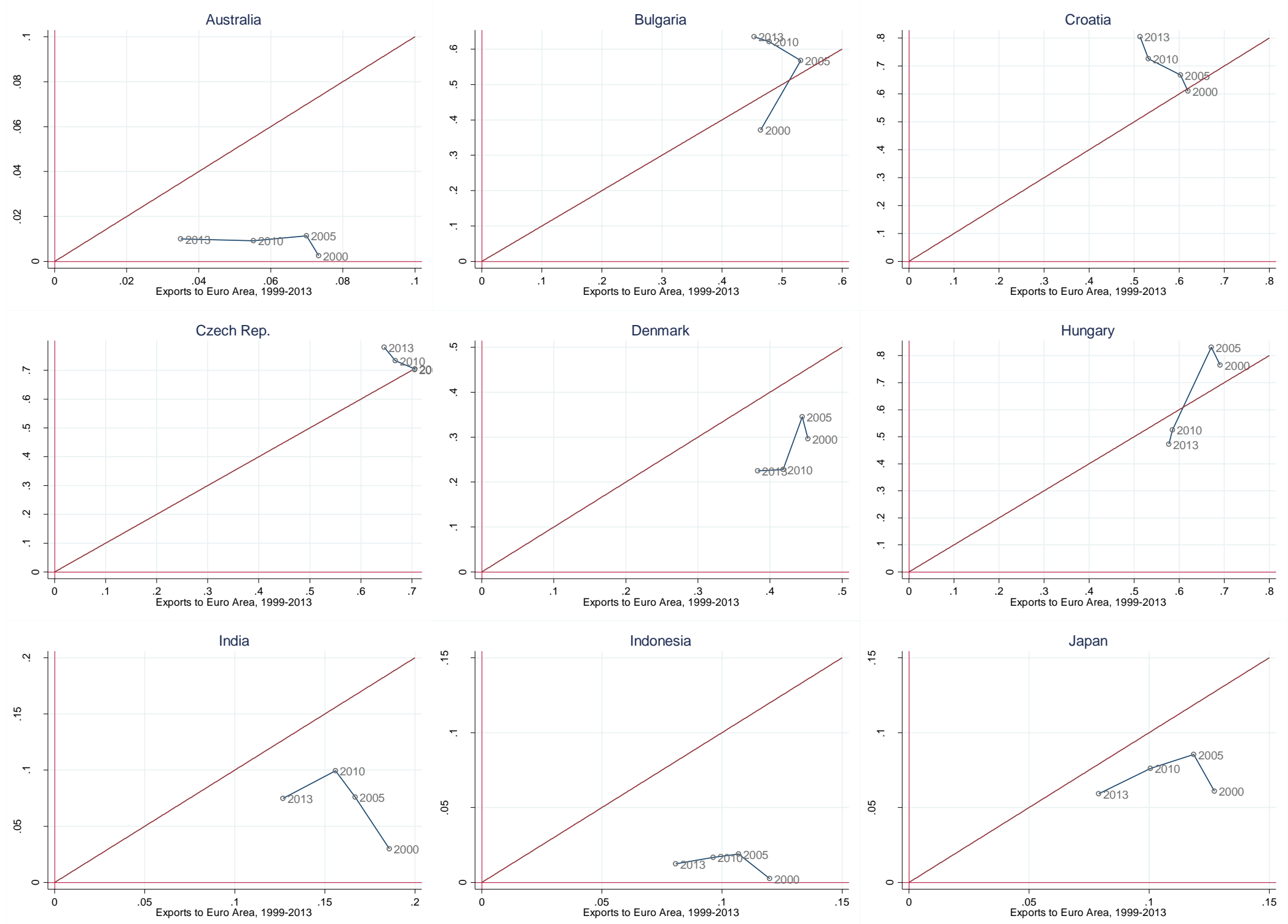
Figure 3-3 (cont'd)
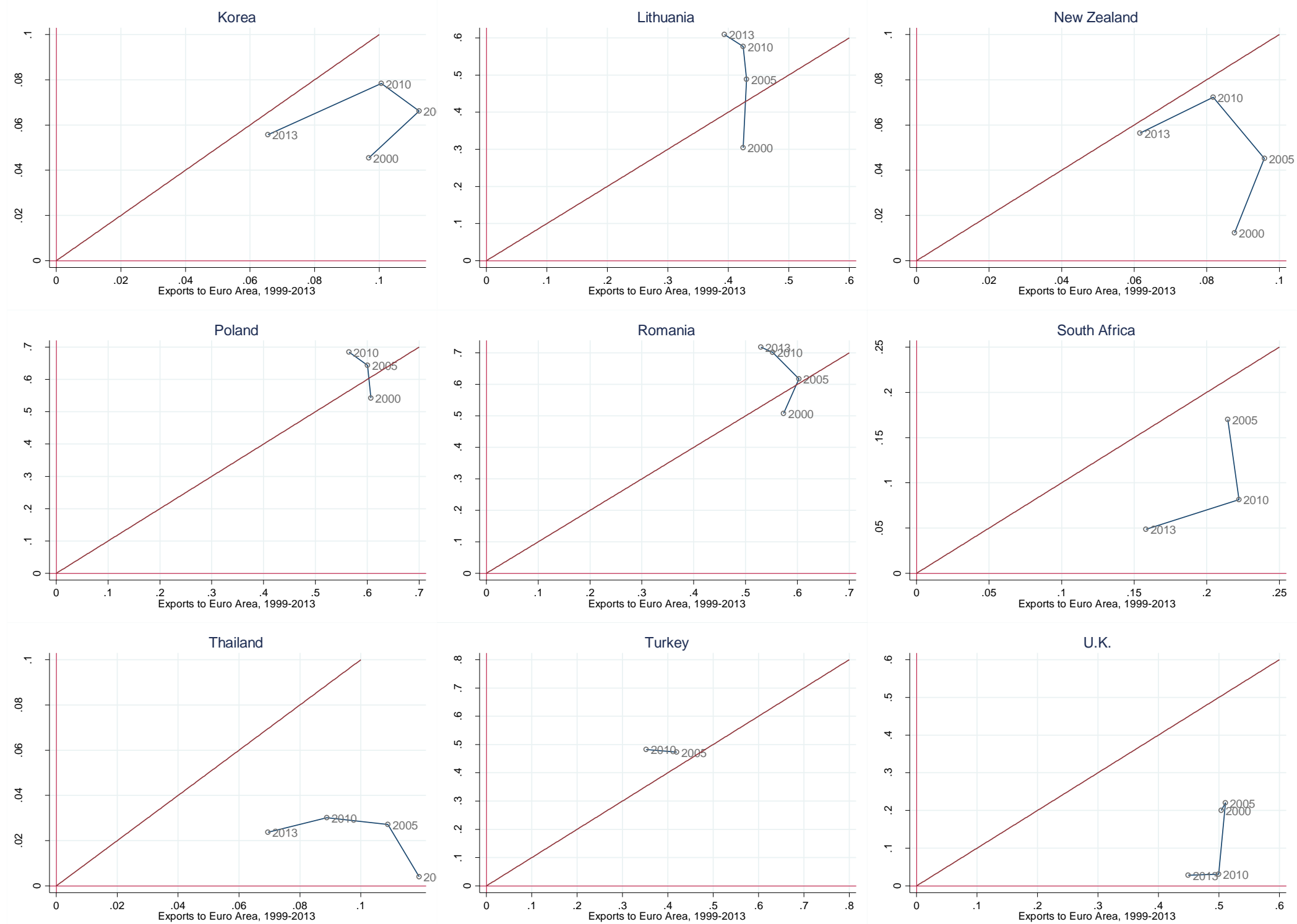
Figure 4: Home Currency Invoicing and the World Export Share, Average 2009-13

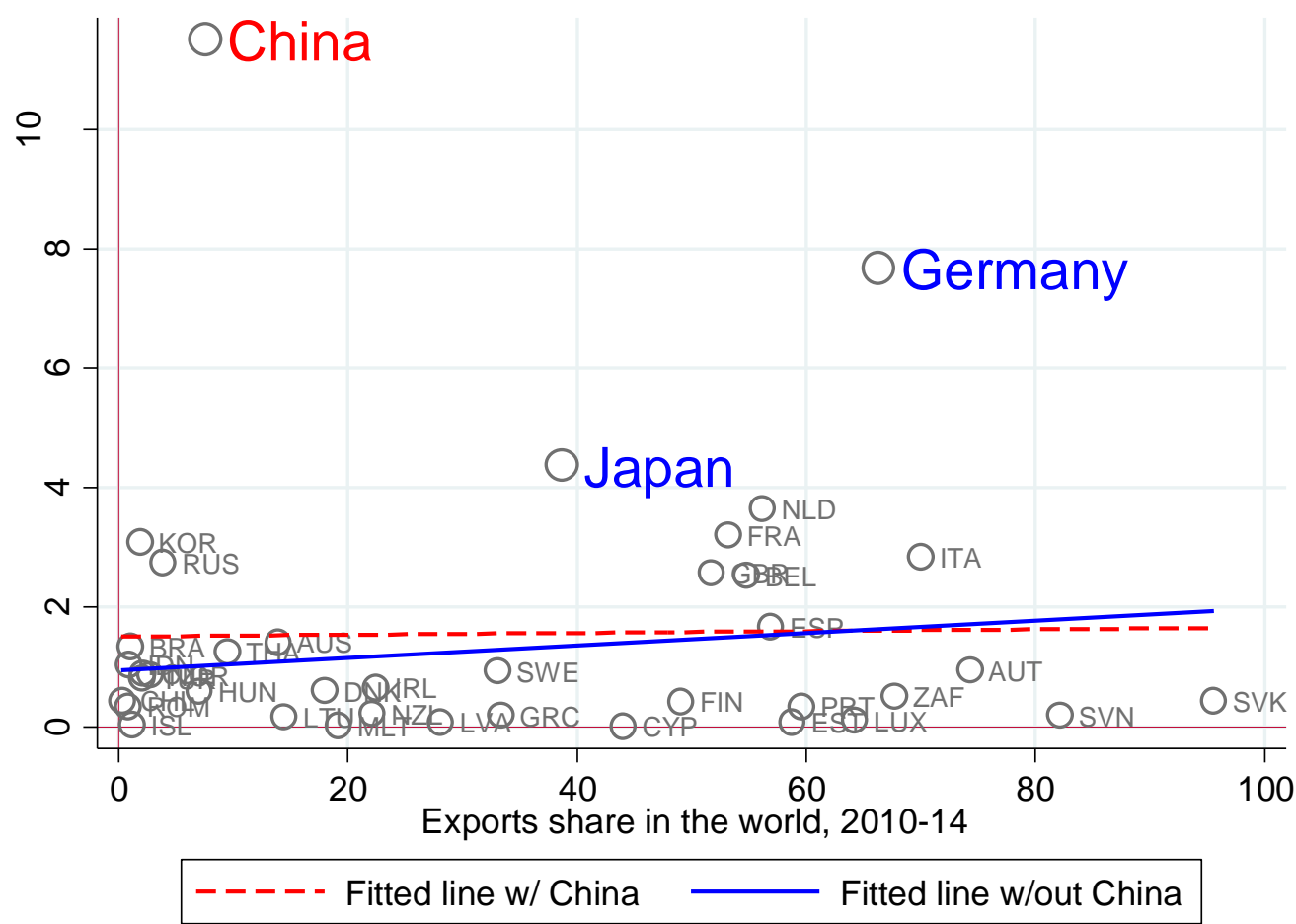

Figure 5: Home Currency Invoicing for Export and Import: Japan, Germany, and China

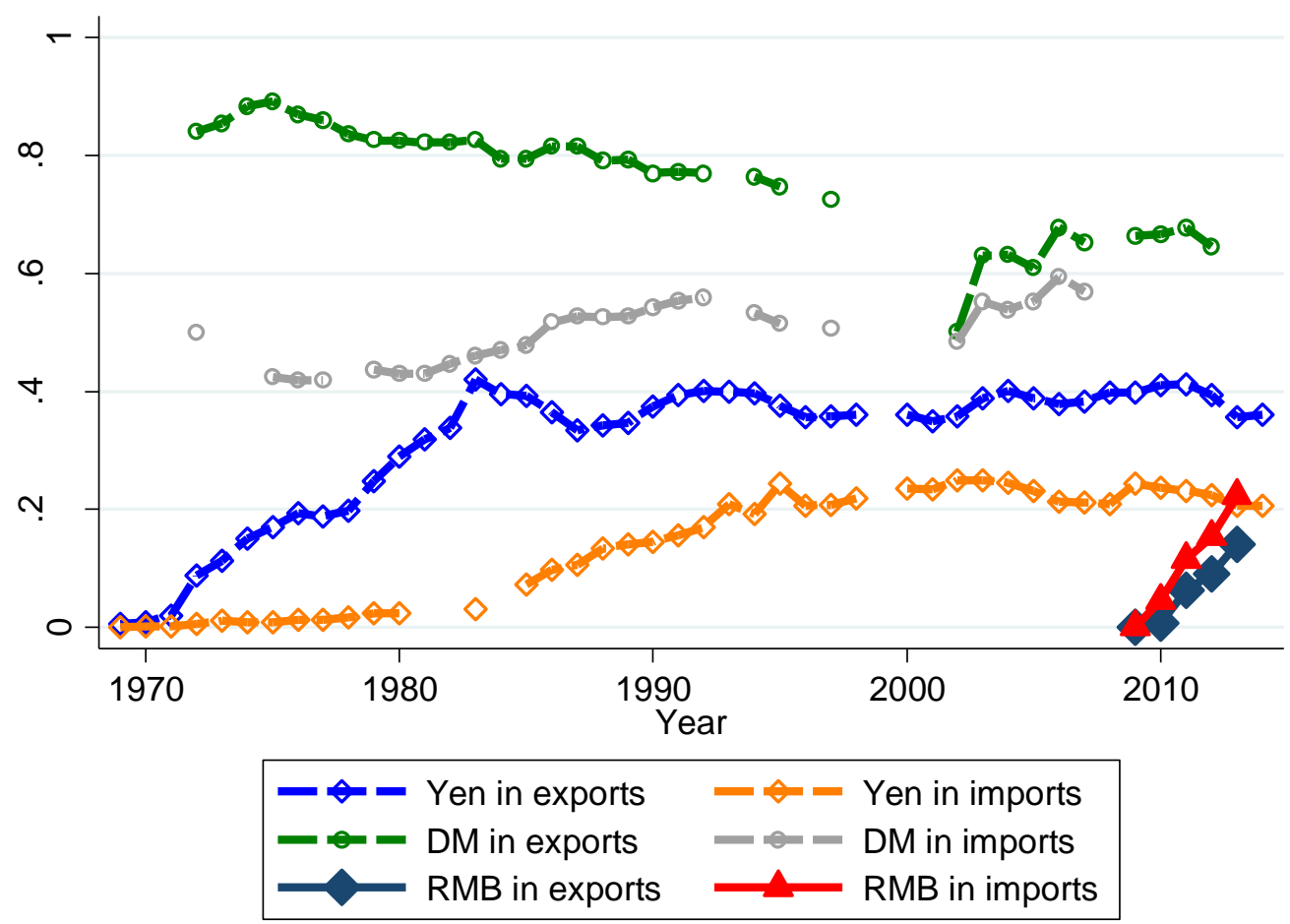


Figure 6: Prediction of Yen Invoicing under the Assumption of Japan's Economic Variables Maintained at Their Peaks

(a) Export Invoicing

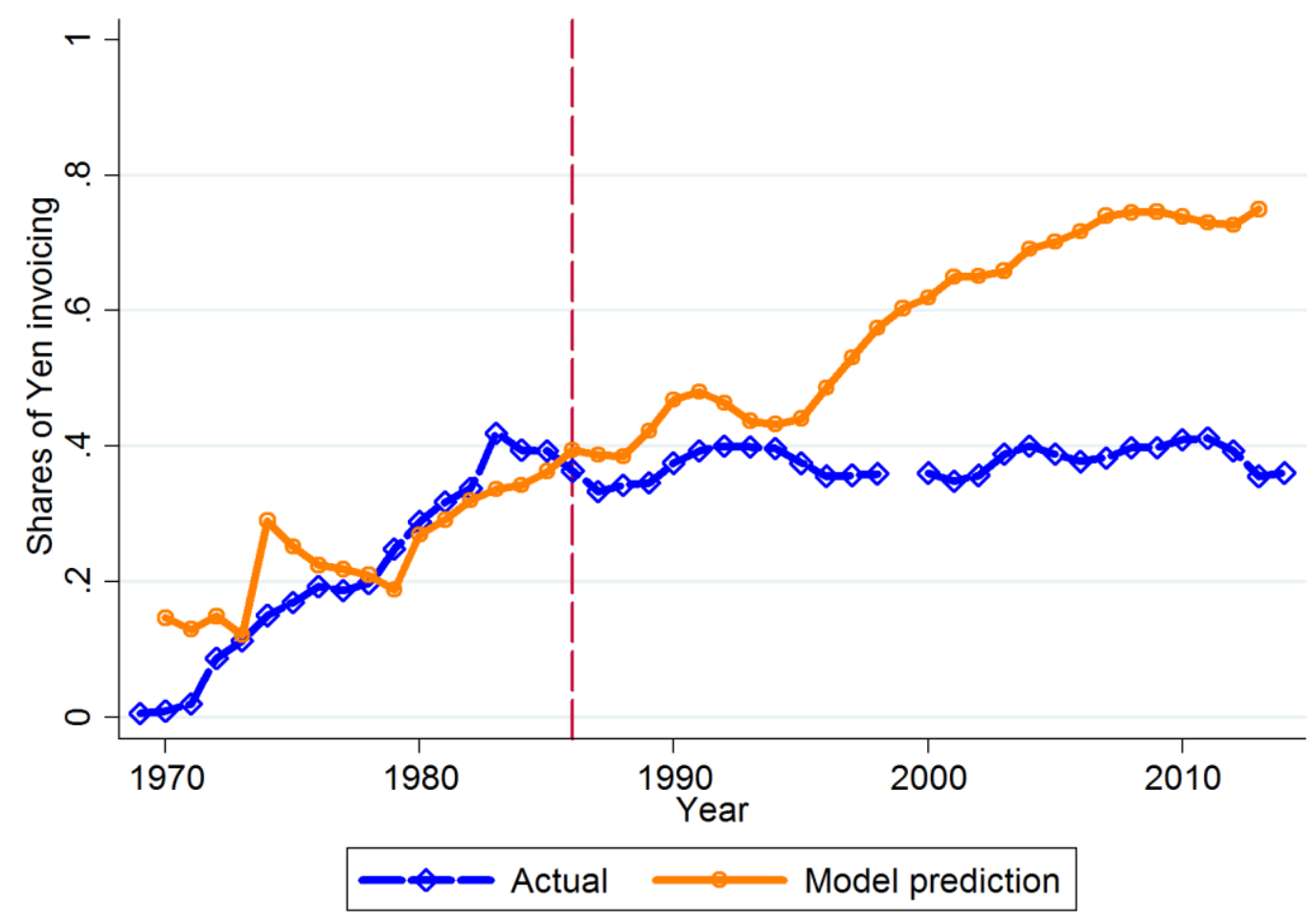

(b) Import Invoicing

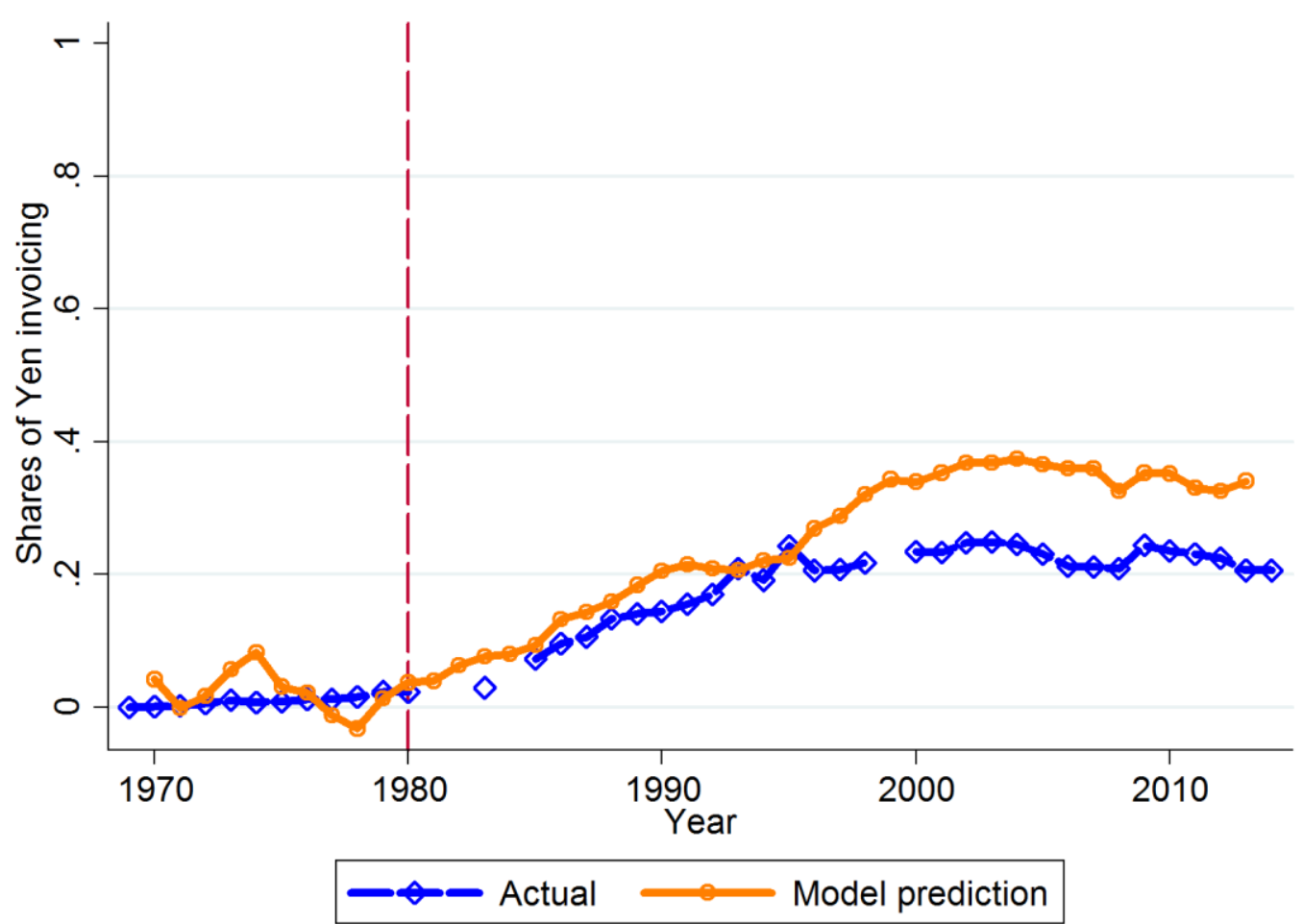

